\title{
Dynamic Performance of Packed-Bed Dehumidifiers: Experimental Results from the SERI Desiccant Test Loop
}

\author{
C. F. Kutscher \\ R. S. Barlow
}

August 1982

Prepared Under Task No. 1132.11

WPA No. 315-81

Solar Energy Research Institute

A Division of Midwest Research Institute

1617 Cole Boulevard

Golden, Colorado 80401

Prepared for the

U.S. Department of Energy

Contract No. EG-77-C-01-4042 
Printed in the United States of America

Available from:

National Technical Information Service

U.S. Department of Commerce

5285 Port Royal Road

Springfield, VA 22161

Price:

Microfiche $\$ 3.00$

Printed Copy $\$ 4.50$

\begin{abstract}
NOTICE
This report was prepared as an account of work sponsored by the United States Government. Neither the United States nor the United States Department of Energy, nor any of their employees, nor any of their contractors, subcontractors, or their employees, makes any warranty, express or implied, or assumes any legal liability or responsibility for the accuracy, completeness or usefulness of any information, apparatus, product or process disclosed, or represents that its use would not infringe privately owned rights.
\end{abstract}


1

1

1 
SEP

TR -1429

PREFACE

This report details the design of a desiccant test loop and describes the experimental performance of packed-bed desiccant dehumidifiers. This work was performed under Task No. 1132.11 for the U.S. Department of Energy. The authors would like to thank the technician, Harry Pol, who assembled and wired most of the laboratory equipment, and summer intern, Chris Rutland, who improved instrumentation, helped run experiments, and assisted in data reduction. Also, review comments by Terry Penney and Randy Gee of SERI are appreciated.

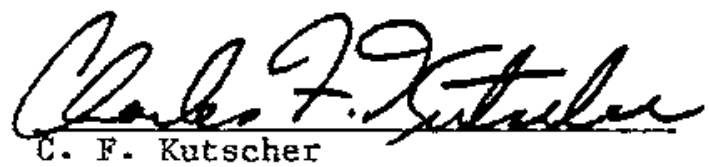

Approved for

SOLAR ENERGY RESEARCH INSTITUTE

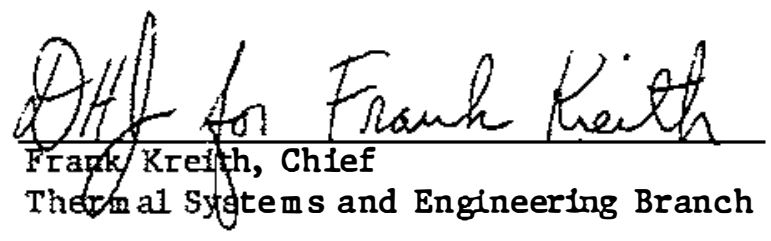

Barn 7 Butter

Barry Buyer, Manager

Solar Thermal and Materials Research

Division 


\section{SUMRARY}

\section{OBJECTIVE}

The objectives of this task were to design and bulld a flexible desiccant test loop, to determine dynamic adsorption/desorption performance, and to validate an in-house computer model.

\section{DISCUSSION}

Packed desiccant beds are of interest in solar cooling applications because they can dry air to a condition suitable for passage through an evaporative cooler, while solar energy can supply the heat for desiccant regeneration. To test various concepts in desiccant bed design vand various desiccant materials, SERI staff constructed a test loop composed of two centrifugal fans, two duct heaters, a steam humidifier, $24.4 \mathrm{~m}$ (80 ft) of $0.30-\mathrm{m}$ (12-1n.) circular duct, instrumentation, and a test section. Desiccant beds are tested in both adsorption and regeneration modes at flow rates up to $0.340 \mathrm{~kg} / \mathrm{s}$ (600 scfm) and at regeneration temperatures up to $120^{\circ} \mathrm{C}\left(248^{\circ} \mathrm{F}\right)$.

The first serles of test runs measured the adsorption/desorption performance of a 74-cm (29-1n•) diameter, 3.2-cm (1.25-in.) thick sillca gel packed bed for a varlety of inlet air conditions. Pressure drop across the bed was measured as a function of flow rate. The adsorption/desorption results were used to validate a SERI desiccant simulation computer model, DESSIM.

\section{COHCLUSIONS AND RECORRMATIONS}

Results from experimental adsorption runs agreed with DESSIM predictions to within 5\%. To obtain agreement for desorption runs to within $20 \%$, it was necessary to change the Lewis number in the model from 3 to 9 . ( $\mathrm{Le}=\mathrm{h} / \mathrm{gC}$ p where $h$ is the heat transfer coefficient, $g$ is the mass transfer coefficient, and $C_{p}$ is constant pressure specific heat.) This indicates that mass transfer occurs more readily in the adsorption direction than in the desorption direction. Pressure drop data indicated that in a 2.5-cm(1-in.)-thick, 8-10-mesh silica gel bed supported by steel screens $\left[1.3-\operatorname{am}\left(0.05-1 n_{\bullet}\right)\right.$ holes on 2-mm (0.081-in.) staggered centers], two-thirds of the total bed pressure drop was caused by plugging of the screen holes.

To maximlze the ratio of Stanton number to friction factor and, thus, Improve overall performance, future SERI experiments in the desiccant laboratory will focus on testing channel flow beds. In these designs a layer of silica gel is glued to parallel plastic sheets with air flow parallel to the sheets. This offers significant promise of reducing required fan power. 


\section{SECTIOR 1.0}

\section{INTRODOCTION}

Three basic concepts for using solar energy to cool buildings have recelved the bulk of U.S. Department of Energy research funding: absorption chillers, which use chemical absorption of an absorbent (such as 11thium bromide) to compress a refriger ant (such as water) in a closed refrigeration cycle and use solar energy to drive the refrigerant vapor from the absorbent-refrigerant solution; Rankine cycle engines, which use solar energy to boll a volatile working fluid that drives the compressor of $a$ heat pump; and desiccant coolers, which essentially use chemical adsorption to compress a refrigerant and use solar energy to drive off the refrigerant (1.e., regenerate the desiccant).

Both solid and liquid desiccants have been used in various configurations for cooling. The most often studied system to date, developed and tested at the Institute of Gas Technology (IGT), is the Solar-MEC (see Fig. 1-1), an opencycle system in which the desiccant is used to remove molsture from an air stream, which is then evaporatively cooled and supplied to the conditioned space (Wurm et al. 1979). A separate air stream is heated by solar energy (as well as an auxiliary fuel), blown through the desiccant bed to remove the molsture, and then discharged into the atmosphere. Both adsorption and regeneration occur simultaneously in the Solar-MEC machine because the bed is divided Into two half-circular sections and rotates, much like rotary sensible heat exchangers that recover heat from exhaust air streams.

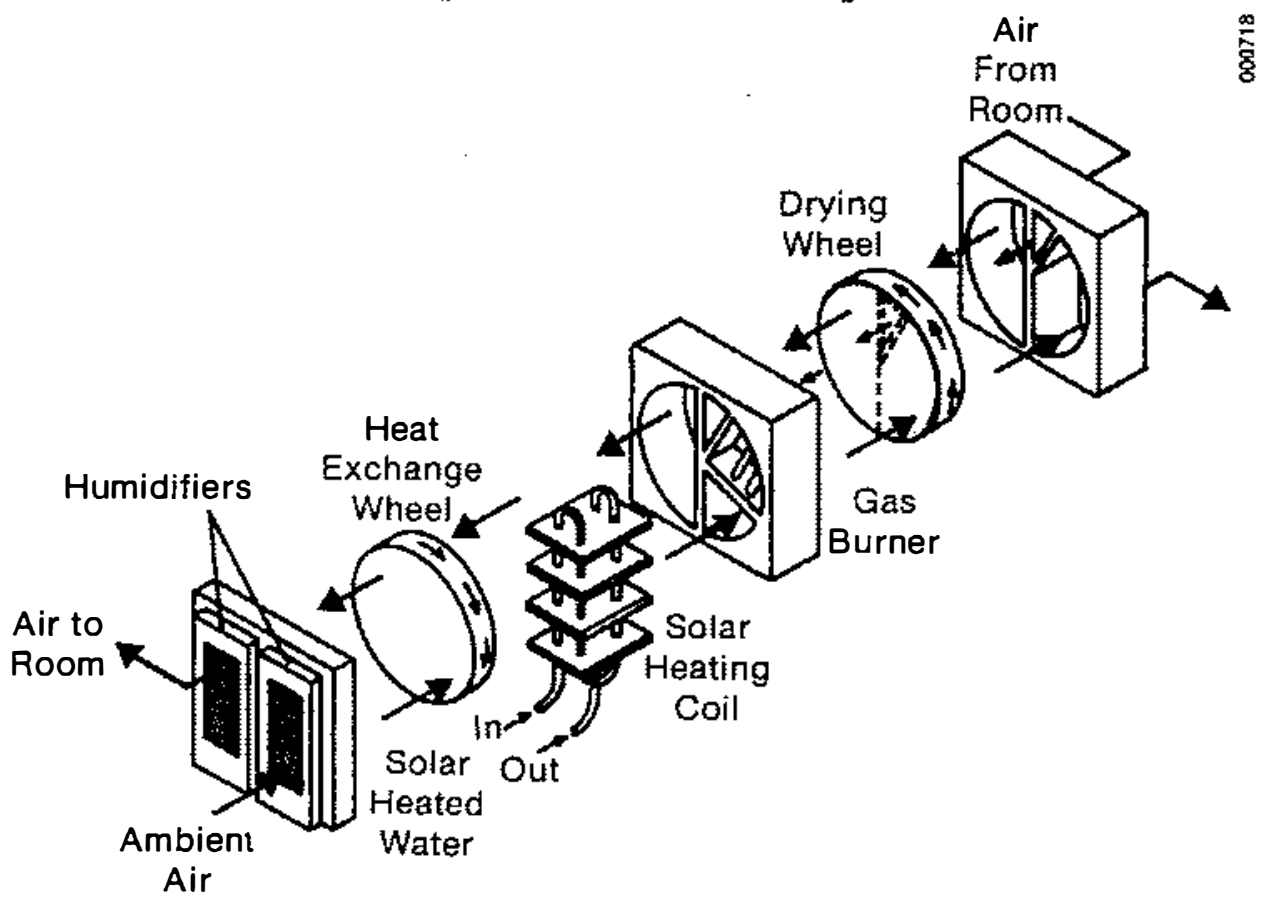

Pigure 1-1. Solar MBC Unit 
In its capacity as the lead laboratory in desiccant cooling research, the Solar Energy Research Inst1tute (SERI) began to study the performance of deslccant beds of the type used in the Solar-MEC machine from both experimental and analytical viewpoints. One result of the analytical work has been the completion of a dynamic desiccant simulation model called DESSIM; some results of that model are discussed later in Sec. 3.0 [see Barlow (1981) for a detailed description of DESSIM] - The experimental work has focused on the development of a test loop to test desiccant beds of different sizes, materlals, and geometries and to validate SERI's computer model. Its construction, operation, and first test results are detalled in this report. 
SECTION 2.0

\section{THR TEST LOOP DESIGA}

\subsection{CONRIGURATION}

The desiccant test loop was conceived to permit dynamic adsorption/desorption tests of full-scale $(74-\mathrm{cm})$ desiccant beds.

Basic parameters designed for were

\author{
Maximum flow rate: \\ Maximum inlet adsorption temperature: \\ Maximum relative humidity: \\ Maximum inlet regeneration \\ tempera ture:
}

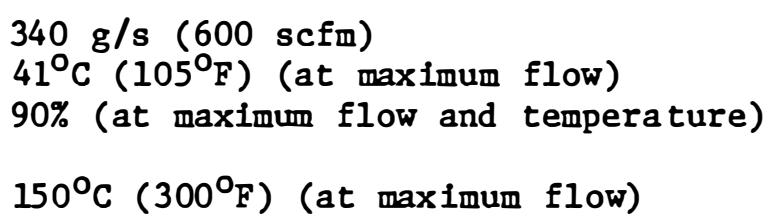

The maximum relative humidity, $90 \%$ at $41^{\circ} \mathrm{C}$, yields a very high humidity ratio that allows testing well beyond the typical humid air design conditions.

To minimize duct heater requirements, the test loop was designed to use room air. We found that room air ordinarily is sufficiently low in both dry-bulb temperature and moisture content (thanks to both the building HVAC system and the dry Colorado climate) to permit desiccant testing over the range of desired conditions. Whether adsorption or desorption testing is done, room air is humidified and/or heated, passed through the test article, and discharged as exhaust out the building.

Because it is sufficiently $\mathrm{r}$ igid and leak-proof, a 30-cm(12-in.)-diameter, 22-gauge spiral duct was chosen. Two duct heaters were purchased--one $6 \mathrm{~kW}$ for adsorption air heating, the other, $35 \mathrm{~kW}$, for regeneration air heating. A two-stage, 50-kW compact electric boller [0-10.3 $\left.\times 10^{6} \mathrm{~Pa}(0-15 \mathrm{psig})\right]$ was chosen for steam production because the building safety codes require vertical stack exhaust for a gas boiler, and the lab is located on the first floor of a four-story building. The boller and duct heaters were all sized conservatively.

Two belt-driven centrifugal fans are used, each with a 30-cm(12-in.)-diameter, straight radial blade wheel. Each has an externally mounted, 2-speed ( 1140 and $1725 \mathrm{rpm}), 230-V$, single-phase, 994-W (1-1/3-hp) electric motor. A stepped-cone pulley system is also used to achleve up to eight different fan speeds in all. Major components were connected via the $30-\mathrm{cm}(12-\mathrm{in} \cdot)$ duct and 12-bolt flanges and supported on stands approximately $1 \mathrm{~m}(3 \mathrm{ft}$ ) above the floor. Bolted flanges were used liberally so that the configuration of the loop could be changed quickly, in case problems arose.

The original arrangement is shown in Fig. 2-1. For adsorption, fan F-1 was turned on. Room air was heated by the 6-kW duct heater to a maximum temperature of $41^{\circ} \mathrm{C}\left(105^{\circ} \mathrm{F}\right)$. The air then passed through a mixing box where steam was injected to humidify the air. The humidifier inside the mixing box contains a coiled steam pipe that wraps around the spray canister to keep the steam spray hot and of high quality. Air was bypassed around the test article 


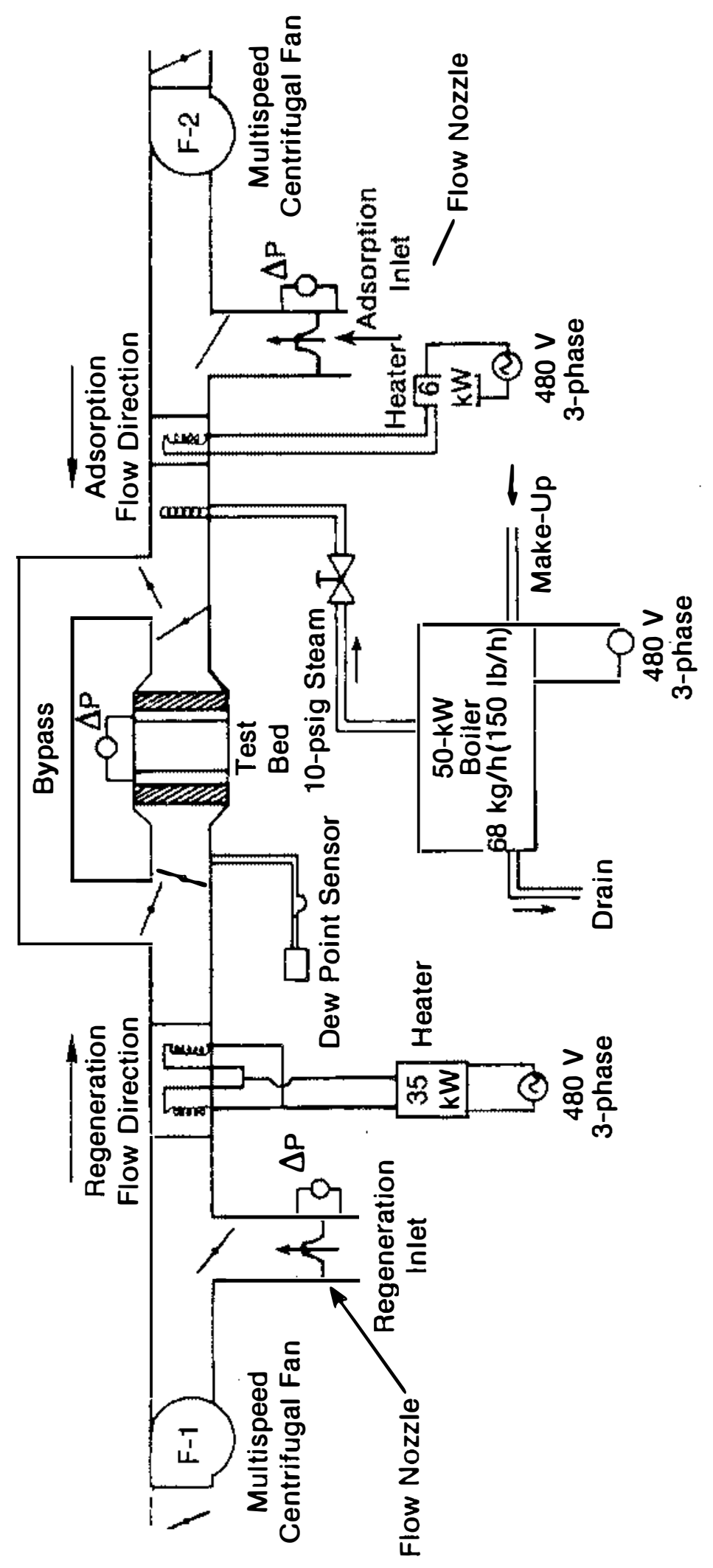

ปี 
until inlet flow, temperature, and humidity were at the desired value. Once the preferred conditions were achleved, sliding gate dampers were used to send flow through the test article and out of the building. In the regeneration mode, fan F-2 was turned on. Room air was heated by the $35-\mathrm{kW}$ duct heater and bypassed around the test bed. Once again, sliding gate dampers were used to direct air flow through the article and out the bullding.

As noted, we encountered a number of problems in this first test loop design. The test $\mathrm{rig}$ was designed to fit into the laboratory with all major components in one stralght run. Thermocouples on elther side of the test article displayed considerable error because of radiation from the duct hea ters. Most radiation shields are designed to block radiation coming from the duct walls ( $1 . e ., 90^{\circ}$ to flow direction) and not axially. It was difficult to block the radlation without elther lmpeding flow over the thermocouple (with a small local shield) or significantly increasing sys tem head loss (e.g., with baffles). Also, a large temperature gradient could be observed at the test article entrance when thermocouple traverses were made across the duct cross section, which was attributed to insufficient mixing length downstream of the duct heaters.

In the original configuration, all system components were located on the suction side of the fans to minimize the chance of desiccant dust leaking into the room and because the alr flow seemed to be more unfform on the suction side. Running the experiment under negative pressure made finding leaks quite difficult, however. The flow nozzles (one for each direction) were located Inside side branches of the duct to allow sufficlent duct length upstream and downstream. (In this way, flow would never occur backwards through the unused nozzle, which could result in a large sys tem head loss.) However, there were a number of potentlal leak sites between the measuring points and the test article as a result of the placement of the nozzles.

To solve these problems, the researchers studied a number of alternative conflgurations. Limited laboratory space and fixed obstacles (e.g., a column, a laboratory sink) were major constraints. The configuration chosen (the one now in use) is shown in Fig. 2-2. The new design provides considerable lengths of stralght duct on both sides of the test article. The $35-\mathrm{kW}$ heater now has $1.2 \mathrm{~m}(4 \mathrm{ft})$ of $\mathrm{s}$ tralght duct on both sides. The elbow downstream of the duct heater further mixes the alr and blocks radlation to the test bed and ins trumenta tion.

Similarly, on the adsorption side, heating of the air and steam injection occur well upstream of the test article, 1solated by two $90^{\circ}$ bends. The fan and elbow provide good mixing. On the regeneration side, note that the fan is located upstream of the $35-\mathrm{kW}$ heater, because higher mass flow rates are achleved by blowing $21^{\circ} \mathrm{C}\left(70^{\circ} \mathrm{F}\right)$ room alr rather than $66^{\circ}-120^{\circ} \mathrm{C}\left(150^{\circ}-248^{\circ} \mathrm{F}\right)$ regeneration air. No te also that most of the test rig is under positive pressure in the current design, which makes leak detection easler. Only leaks between the flow nozzles and test bed are critical. The problem is minimized by the proximity of the flow nozzles to the test bed.

The new test rig became operational in October 1980. Problems with the previous design had been elther solved or greatly alleviated. Although the radial temperature gradients in the duct were greatly reduced, we could still 


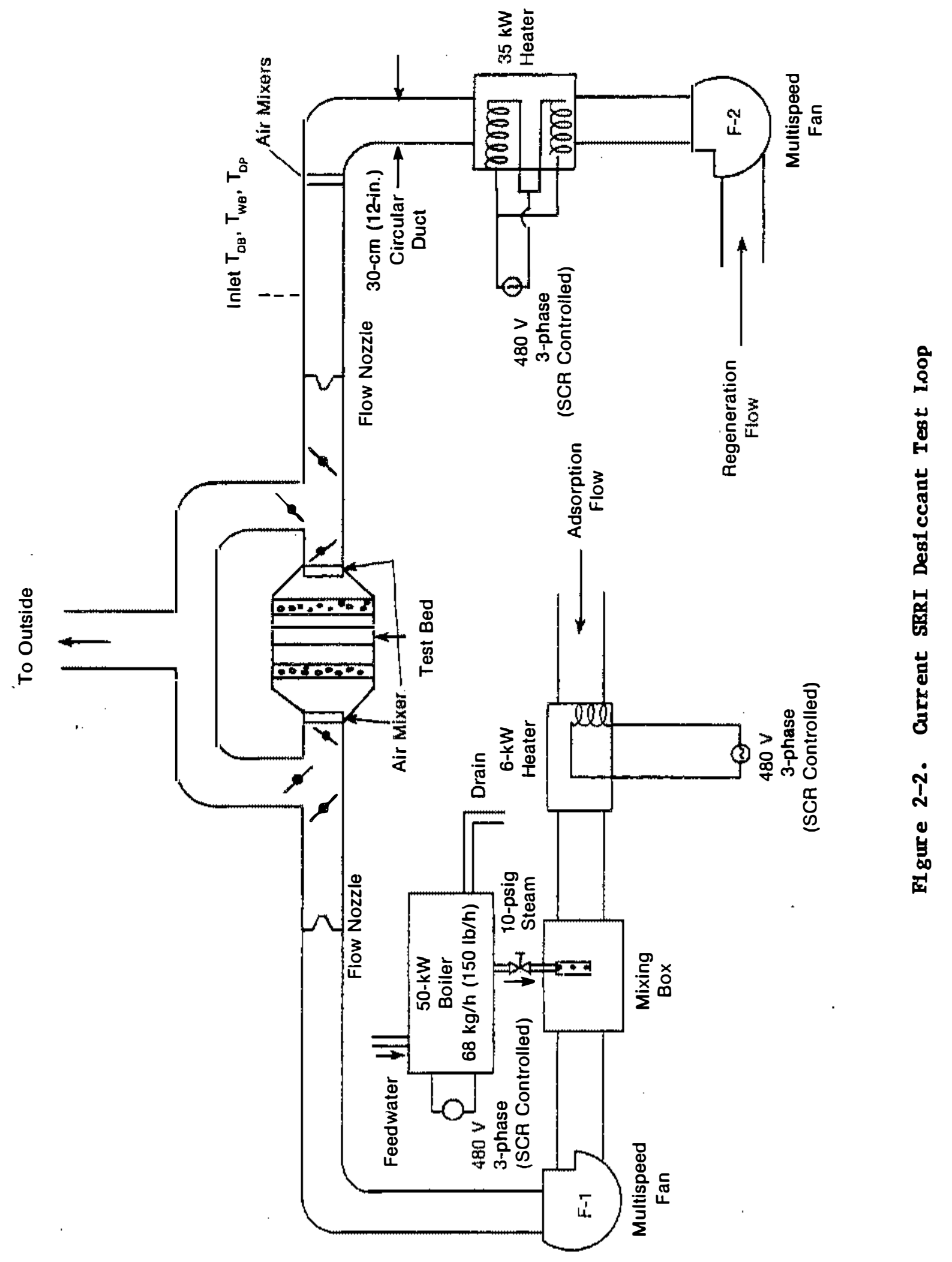


detect as much as a $3^{\circ} \mathrm{C}\left(5^{\circ} \mathrm{F}\right)$ variation at $66^{\circ} \mathrm{C}\left(150^{\circ} \mathrm{F}\right)$. Fortunately, we found a local shop to manufacture air mixers, which did an excellent job of mixing with a minimal pressure drop. Figure 2-3 illustrates the air mixer. One mixer was installed just downstream of the elbow that follows the $35-\mathrm{kW}$ heater; this reduced the temperature gradient to less than $1^{\circ} \mathrm{C}\left(2^{\circ} \mathrm{F}\right)$. Because of their low pressure drops, two more mixers were installed, one on each side of the test article.

Before useful data could be taken, it was necessary to $f 1 x$ the leaking gate dampers used to establish flow direction. Although inexpensive "blast gate" dampers sealed reasonably well inside the duct, we found that a large amount of air leakage occurred along the blades to the outside of the duct. It was very difficult to achieve a good seal on the open slits of the external flange in which the damper blade slides. The solution was to cut of the external flange and build a wooden framework, which could be covered easily with closed-cell foam and another block of wood (see Fig. 2-4). The damper blade is either completely inserted or completely removed. To change a damper, it is a simple and quick procedure to open a cover, add or remove a damper, and replace the cover. This effectively eliminated the external leakage problem.

Butterfly dampers on elther side of the fan control flow rate by throttling. They are also used in the bypass legs to allow bypass system pressure drop to match the pressure drop that occurs through the desiccant bed, resulting in a changeover from bypass to through-flow without a change in flow rate. Although the dampers leak slightly where the handle shaft plerces the duct, none are located in the critical area between the flow nozzles and the test article. After all other leaks were found (by smoke testing) and sealed, $5 \mathrm{~cm}$ (2 in.) of foll-covered fiberglass insulation were installed over all ducts and components downstream of the heaters. Heat loss has been somewhat higher than calculated because the $5-\mathrm{cm}$ fiberglass was partially compressed when it was installed, even though great care was' taken to minimize this. However, this is not a problem because temperature measurements are made very close to the test article.

\subsection{CONTROLS}

The test loop was designed for local analog control of each duct heater and the boller. The 480-V, 3-phase power to each duct heater is wired through a silicone controlled rectifier (SCR)--one for each heater. The firing of each SCR is controlled by a simple proportional analog controller that adjusts current based on the difference between a set point temperature and that measured in the duct by a type $T$ (copper-constantan) thermocouple. Desired temperatures are reached rapidly, and the SCRs are stable down to about $10 \%$ of full power.

Controlling steam input to the duct has been a source of problems. A proportional analog controller of the type used for the duct heaters initially was employed to control output voltage to an electrically operated globe valve in the steam supply line, based on a comparison between a set point relative humidity and the output of a resistance-type $\mathrm{RH}$ sensor in the duct. In practice, the valve tended either to oscillate or to remain in one position. Relocating the sensor element and throttling flow upstream of the globe valve did not 


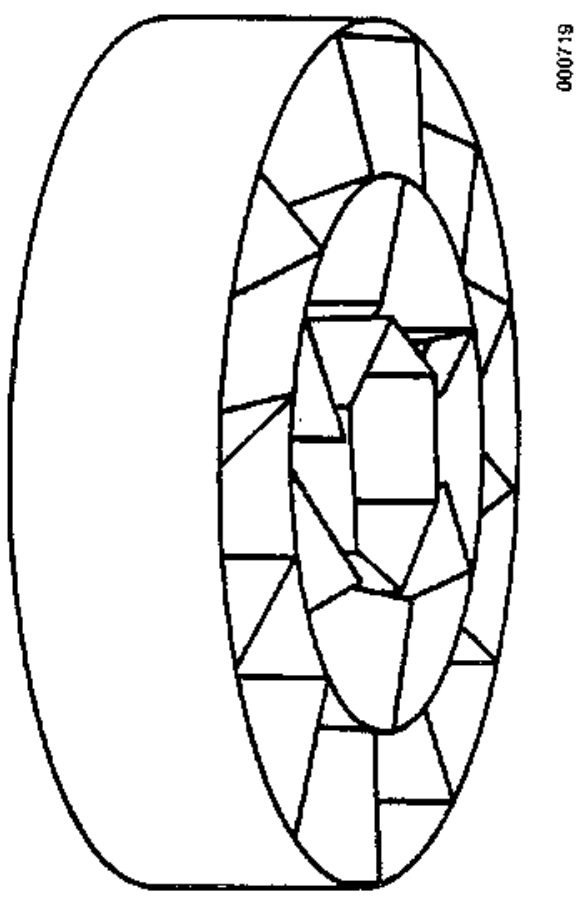

P1gure 2-3. F10r tixer

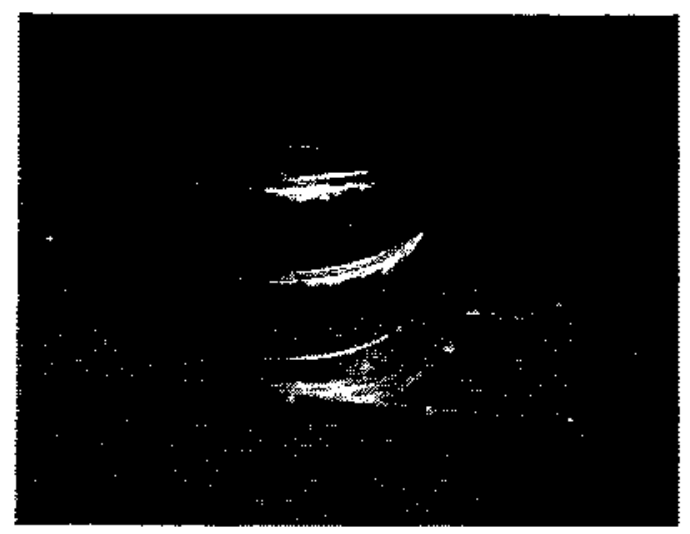

Old

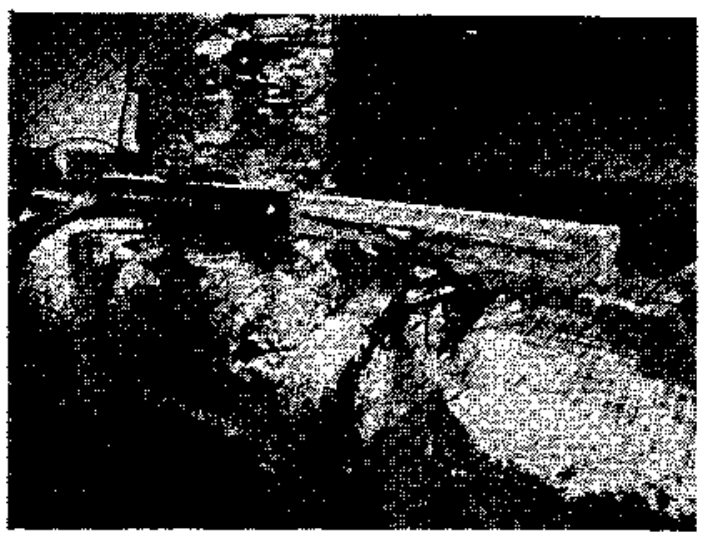

New

F1gure 2-4. Old and New Damper Designs 
solve the problem. Since air flow rate and inlet moisture content are steady during an experimental $\mathrm{run}$, we decided to set the steam line valves in fixed positions and operate the boiler in steady state. The original pressurecontrol device on the boller had a minimum pressure range setting of $0.41 \times 10^{3} \mathrm{~Pa}$ differential (6 psid). So, for example, the boller elements (two separately switchable $25-\mathrm{kW}$ imersion heater bundles) would turn on at a gauge pressure of $0.41 \times 10^{3} \mathrm{~Pa}(6 \mathrm{psig})$ and turn off at $0.83 \times 10^{3} \mathrm{~Pa}$ (12 psig). Unfortunately, this change was sufficiently large to cause significant variations in steam input.

A pressure controller with a $6.9 \times 10^{3} \mathrm{~Pa}(1-\mathrm{ps} 1)$ pressure range was installed, but even this variation resulted in inlet dew-point variations of $\pm 0.5^{\circ} \mathrm{C}$, producing a definite waviness in input humidity with a typical periodicity of four minutes. To obtain steadier pressure, an SCR was connected to the heater elements and controlled by an analog controller comparing duct air dew point at the test article entrance to a set point value. This setup certainly did not exhibit a rapid response, but as long as a steady pressure could eventually be reached, it was considered adequate.

This new scheme appeared to work well at first. However, the dew point would drop sharply by $0.5^{\circ} \mathrm{C}\left(0.9^{\circ} \mathrm{F}\right)$ about every 15 minutes and then gradually rise again. The dew-point drop coincided with injection of cold boller feedwater through a fast-acting solenold valve. (This valve had earlier caused water hammer problems in the feedwater line, which were solved by the installation of a sma11, pressurized surge tank.) The dew-point drop problem was greatly alleviated when we installed a small metering valve in the feedwater line to prevent the sudden surge of cold water when the solenoid opened.

Additionally, since many test runs required flow rates at a very small fraction of boller capacity, and it was difficult to turn the power down low enough to achieve this, we installed a dump steam condenser, consisting of a simple copper coll in a tank of cold water. The boller was then operated at the minimum controllable level and excess steam was diverted through the coil, where it condensed and dripped into a floor drain.

Operating the boller as described here resulted in inlet dew-point variations of less than $\pm 0.15^{\circ} \mathrm{C}\left( \pm 0.27^{\circ} \mathrm{F}\right)$. Getting to the steady-state condition proved to be tedious and time consuming, however, taking as long as 45 minutes. Recently, a voltage output card for the HP- 35 data acquisition computer was purchased, and the computer was programmed to perform proportional-integral control. The difference between measured dew-point temperature and a set point is used as the error signal. Preliminary results using this system were encouraging.

\subsection{INSTRMARTATION AND DATA ACQUISITION}

\subsubsection{Data Acquisition}

Originally, a Kaye Digistrip-II data logger with a built-in, full-page line printer was used for data acquisition. This data logger can compensate internally for various types of thermocouples, will scale analog and voltage 
inputs, and supply readings in engineering units. It can also perform simple scientific calculations. For example, it was programmed to take the square root of the flow nozzle pressure drop, multiply it by a drag coefficient, and output a flow rate. Up to 70 channels could be input with a scan rate of 8 channels per second.

Early in the data runs, we realized the importance of being able to perform real-time psychrometric conversions as well as corrections such as the radiation effect on wet-bulb measurement. At the same time, data acquisition systems, priced under $\$ 10,000$, that had such a capability were becoming available. According1y, an $\mathrm{HP}-85$ data acquisition system was purchased, consisting of an HP-85 desktop computer with an HP-3497 scanner/multiplexer/digital voltmeter.

The software, written in BASIC, was designed to convert all voltage readings from the HP-3497 into engineering units as well as perform psychrometric calculations such as determining humidity ratio from either dew-point or wet-bulb temperatures. A sample output is shown in Fig. 2-5. Values for the left (absorption inlet, regeneration outlet) and right (absorption outlet, regeneration inlet) sides of the test article are displayed. Inlet and outlet drybulb temperatures, wet-bulb temperatures, and the percentage of relative humidity are shown, as well as the flow rate. Inlet and outlet humidity ratios are calculated based on dew-point and dry/wet bulb temperatures. Inlet and outlet enthalples are also calculated. Measurement locations are shown in Fig. 2-6.

Al1 the data are displayed every 15 seconds and can be printed out every 30 seconds. The software also contains a graphics section for plotting outlet dry-bulb temperature versus time, outlet humidity ratio versus time, and the process line on a psychrometric chart. As noted in Sec. 3.0, the-program now also contains the software for performing proportional-integral control of the steam supply valve.

\section{BEGIN DATA COLLECTION}

TIME: $00: 00 \quad 09: 29 \quad 03 / 01 / 81$

ADSORFTION FLOW RATE $=3$ SCFM

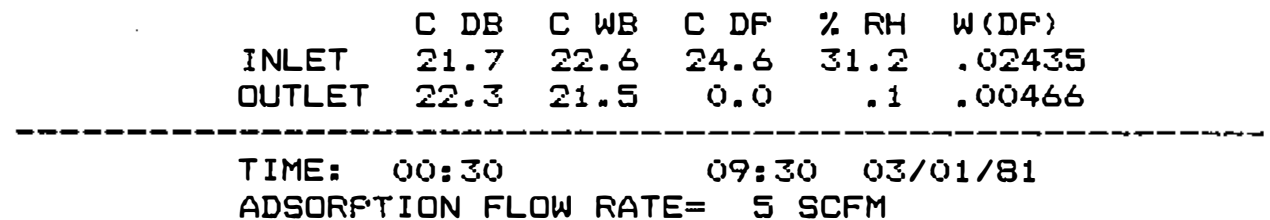

\begin{tabular}{ccccccc} 
& $C D B$ & $C$ & WB & C DF & $\%$ RH & $W(\mathrm{DF})$ \\
INLET & 21.7 & 22.6 & 24.6 & 31.3 & .02439 \\
OUTLET & 22.3 & 21.6 & 0.0 & .1 & .00466 \\
\hline END DATA COLLECTION: AVE FLOW RATE & 4.2453 & SCFM $=$ & $2.37366850319 E-3 \mathrm{KG} / \mathrm{S}$
\end{tabular}

Pigure 2-5. Sample HP-85 Data Acquisition Systen Output 


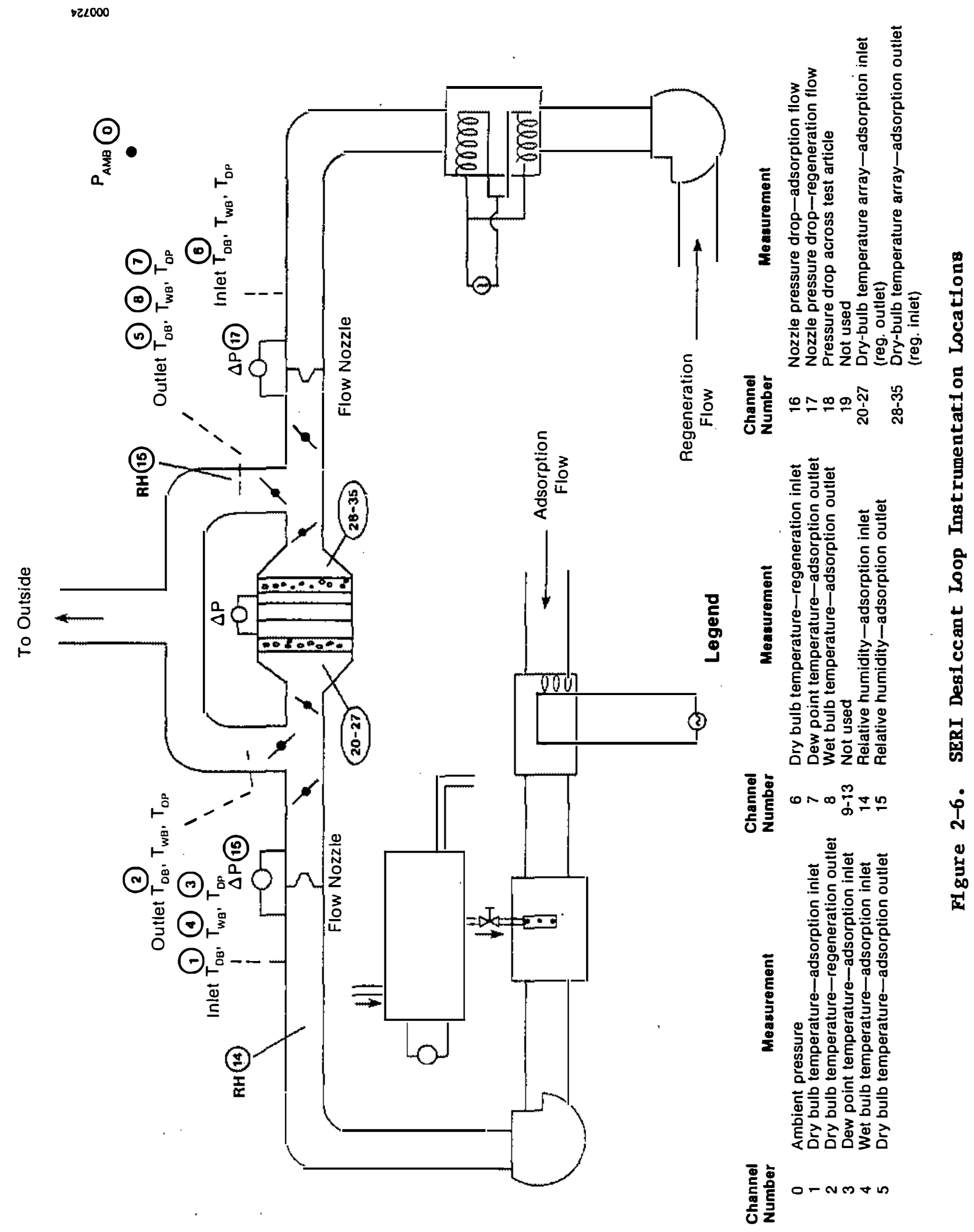




\subsubsection{Temperatures}

Temperatures throughout the system are measured with exposed-junction type-T (copper-constantan) thermocouples having a rated accuracy of $\pm 0.5^{\circ} \mathrm{C}$. Reference compensation is accomplished by the data acquisition system (isothermal block). Although the system design permits good air mixing, any variation is averaged by means of an array of thermocouples mounted on wire screens, one screen on each side of the test article. Each screen contains eight thermocouples positioned to yleld an area-welghted average. Each thermocouple is read into the data acquisition computer, and averaging is accomplished in the software. This allows temperature distributions to be observed. Because of the high conductivity of the copper wire, at least $15 \mathrm{~cm}$ ( 6 in.) of wire is used between the duct surface and each thermocouple to minimize conduction error.

\subsubsection{Pressure Drops}

Pressure drops are determined by capacitance-type pressure transducers, MRS Model 221, that supply an output of 0-10 VDC proportional to a pressure drop of $0-24 \mathrm{~Pa}$ (0-10 in. WG) and have an accuracy of $\pm 0.5 \%$ of the reading. A sealed capacitance-type unit is also used to measure atmospheric pressure. For more accurate visual readings, a hook gauge manometer (Dwyer Model 1430 micrometer) with a range of $0-498 \mathrm{~Pa}(0-2 \mathrm{in.})$ and an accuracy of $\pm 0.025 \mathrm{~Pa}$ $( \pm 0.0001 \mathrm{in}$.$) is used.$

\subsubsection{F100 Rates.}

Flow rates are determined by ASME flow nozzles, flange-mounted in the 30-cm (12-in.) duct. Nozzle sizes of $4 \mathrm{~cm}(1-5 / 8 \mathrm{in.}), 5 \mathrm{~cm}$ (2 in.), $6.5 \mathrm{~cm}$ $(2-1 / 2$ in.), $10 \mathrm{~cm}$ ( 4 in.), $13 \mathrm{~cm}$ (5 in.), and $18 \mathrm{~cm}$ (7 in.) (in pairs) allow measurement over a wide range of flows. Pressure drops across the nozzles are measured with the capacitance-type transducers already noted.

\subsubsection{Bnmidity}

Alr dew point is measured with General Eastern Model 1211 optical condensation dew-point hygrometers. Each one contains a thermoelectric heat pump which alternately heats and cools a mirror surface, maintaining it at the dew-point temperature. A type-T thermocouple measures the mirror temperature directly and is routed to the data acquisition computer. To ensure a representative air sample from the duct, the air for each hygrometer is drawn by a small pump from a 2.5-cm(1-in.)-diameter, 30-cm(12-in.)-long copper pipe whth 12 manifold holes, each $1.8 \mathrm{~mm}(0.070 \mathrm{in.})$ in diameter, arranged across the duct perpendicular to air flow. Air is thus sampled from the entire cross section.

Although these hygrometers can provide accurate dew point readings, their performance in the laboratory has been disappointing. Repeatability has been poor, and they tend to go into oscillations without warning. A great deal of attention has been paid to adjusting various controls (compensation, gain, condensate film thickness), but the problems remain. Because of these 
problems, various other humidity measurement devices have been tested. Pope cell-type relative humidity transducers have been used, but they were not sufficiently accurate for our experiments.

Wet-bulb thermocouples were made by inserting a type-T thermocouple inside a cotton wick partially immersed in a reservoir. Adjustments of the length of wick not immersed proved critical. If it is too long, the wick near the thermocouple will not be sufficiently wet, and the reading will be too high. If it is too short, water from the reservoir will be drawn up too rapidly, and the reading will be shifted toward the reservoir temperature. Shielding the thermocouple from radiation is also a difficult problem. When a simple drybulb measurement is taken, a cylindrical metal shield oriented along the flow direction can be placed around a thermocouple. This minimizes radiation heat transfer between the thermocouple and the environment, since the shield itself will tend to be near the air dry-bulb temperature. If the wall temperature differs greatly from the dry-bulb temperature, several shields can be used. When we attempt to measure wet-bulb temperatures, however, we find that a simple shield will again be near the dry-bulb temperature, and radiation error will still exist.

In determining the air humidity ratio, the wet-bulb reading must be corrected to account for this radiation heat gain term. This is done by the data acquisition computer. From an enthalpy balance on the thermocouple, the corrected humidity ratio is as follows (Threlkeld 1970):

$$
W=W_{S, B}-\frac{L e C_{p, a}}{h_{f g, w b}}\left[1+\frac{h_{r}\left(T_{S}-T_{w b}\right)}{h_{c}\left(T-T_{w b}\right)}\right]\left(T-T_{w b}\right)
$$

where

$$
\begin{aligned}
& \mathrm{W}= \text { corrected air humidity ratio } \\
& \mathrm{W}_{\mathrm{S}, \mathrm{B}}= \text { humidity ratio of saturated air at the temperature indicated } \\
& \text { by the wet-bulb thermometer } \\
& \mathrm{Le}= \text { dimensionless Lewis number at the wick surface } \\
& \mathrm{h}_{\mathrm{fg}, \mathrm{wb}}= \text { latent heat of vaporization of water at the indicated wet- } \\
& \text { bulb temperature } \\
& \mathrm{C}_{\mathrm{p}_{\mathrm{T}} \mathrm{a}}=\text { specific heat at constant pressure based on dry air } \\
& \mathrm{T}_{\mathbf{S}}=\text { absolute temperature of surrounding surfaces } \\
& \mathrm{T}_{\mathrm{wb}}=\text { absolute temperature indicated by wet-bulb thermometer } \\
& \mathrm{T}=\text { absolute dry-bulb temperature of the air } \\
& \mathrm{h}_{\mathrm{c}}=\text { convection heat transfer coefficient at wick surface } \\
& \mathrm{h}_{\mathbf{r}}=\text { radiation heat transfer coefficient at wick surface. }
\end{aligned}
$$

Using a Lewis member of 0.89 and an empirical correlation for the specific heat at the arithmetic mean humidity ratio, we have (in SI units):

$$
\mathrm{W}=\mathrm{W}_{\mathrm{s}, \mathrm{wb}}-\left[\frac{1003+1880 \mathrm{~W}_{\mathrm{s}, \mathrm{b}}}{\frac{\mathrm{h}_{\mathrm{fg}, \mathrm{WB}}}{0.89\left(1+\mathrm{h}_{\mathrm{r}} / \mathrm{h}_{\mathrm{c}}\right)}+940\left(\mathrm{~T}-\mathrm{T}_{\mathrm{wb}}\right)}\right] \text {. }
$$


The saturated air humidity ratio is determined as follows:

$$
\mathrm{W}_{s, w b}=0.622 \frac{P_{S, w b}}{P-P_{S, w b}} \text {, }
$$

where $P$ is the vapor pressure, and $P_{S}$,wb is the vapor pressure of saturated air at the measured wet-bulb temperature determined from an empirical correlation.

The convective heat transfer coefficient is calculated as

$$
\mathrm{h}_{\mathrm{c}}=1.717 \mathrm{v}^{0.618 \mathrm{~J} / \mathrm{sm}^{2} \mathrm{~K}} \text {, }
$$

where $v$ is the air velocity. The radiative heat transfer coefficient is determined as

$$
h_{r}=56.73 \times 10^{-9} \varepsilon_{w b}\left[\frac{T^{4}-T_{w b}^{4}}{T-T_{w b}}\right] J / s^{2} \mathrm{~K}
$$

where $E_{w b}$ is the emissivity of the white cotton wick, estimated to be 0.85 .

Writing these correlations into the BASIC data acquisition software for the HP-85 computer, we obtain radiation-corrected humidity ratios based on measured wet-bulb temperatures as outputs.

Unfortunately, the wet-bulb thermocouples also proved troublesome. The most important measurement point during an adsorption run, the bed outlet, was of ten too dry for the wet bulb. The wick would dry out and the wet-bulb reading would approach that of the dry bulb. The dew-point hygrometers thus remain our reference measurement for air humidity, and if they become unstable during a test run, that run is repeated. We are continuing to look for more reliable ways of measuring the air humidity. (We recently acquired two new Central Eastern dewpoint hygrometers, Model 1100 DP, which have given good results so far.)

\subsection{TBST PROCEDURB}

To make the test procedure as simple and repeatable as possible, we prepared a step-by-step checklist. Immediately before an adsorption data-taking run, the test bed is completely regenerated [1.e., outlet dry bulb is within $0.2^{\circ} \mathrm{C}$ $\left(0.4^{\circ} \mathrm{F}\right)$ of inlet dry bulbl. Similarly, the bed is completely adsorbed before a data-taking regeneration run is made. The test procedure is set up to make the time between adsorption and desorption as short as possible.

The longest delay occurs between the end of regeneration and the beginning of adsorption, because the inlet humidity must be brought to the proper value. Before regeneration is started, therefore, the boiler is brought up to pressure, and steam is injected into a bypass airstream to achieve the humidity needed for adsorption. This allows us to determine the proper position of a throttling valve upstream of the steam control valve as well as the proper 
electric power setting. The boller is then left at pressure during regeneration. In spite of these precautions, a time lag of 20 minutes still can occur between regeneration and adsorption, so the test bed is removed and sealed in an air-tight plastic bag during that time.

The test procedure provides for preadjustment of the flow dampers, maintaining the correct flow rate when the flow direction is switched from bypass to flow through the test article. After a test run, the bed is weighed on a scale accurate to $\$ 4.5 \mathrm{~g}( \pm 0.01 \mathrm{lb})$ to determine the amount of water adsorbed or desorbed. The fans are run for several minutes after the heaters are turned off to cool down the colls. The step-by-step procedure is detailed in the appendix. 


\section{SEPI}




\section{SECTIOE 3.0}

\section{EXPBRDIERTAL RESULTS}

To obta in data that could be compared directly with data from other sources, the first test article was designed to behave as a portion of a test bed being manufactured by AlResearch Manufacturing Co., a SERI subcontractor (Rousseau 1981). Figure 3-1 shows the AlResearch system. The desiccant bed is a vertical drum design split into halves by a vertical plane through which the drum's axis of rotation passes. Adsorption and regeneration air enter in opposite halves. In each case, air enters (or exits) the core volume of the bed from one end of the drum and passes through the desiccant in a radial direction.

SERI's first test article is shown in Fig. 3-2. It is disk-shaped and represents a portion of the drum wall, thus replacing a cylindrical geometry with a slab geometry, a reasonable approximation of a thin-shelled annular cylinder. The screen used to hold the 8-10 mesh sillca gel in place is the same as that used by AlResearch. The test article rim was made from a rolled steel channel. One circular screen was riveted to one side of the frame. The silIca gel was added with the channel-screen combination horizontal. Once full, the second screen was rlveted in place. Flve metal spacers were used between the two screens to maintain $3.2-\mathrm{cm}\left(1.25-1 n_{0}\right)$ spacing-the same as the AlResearch depth. The bed dlameter of $74 \mathrm{~cm}$ (29 in.) was chosen so that the same face velocity as that of AlResearch could be maintained $[19.8 \mathrm{~m} / \mathrm{s}$ $(65 \mathrm{ft} / \mathrm{s})$ ] with a flow rate of $170 \mathrm{~g} / \mathrm{s}$ (300 scfm).

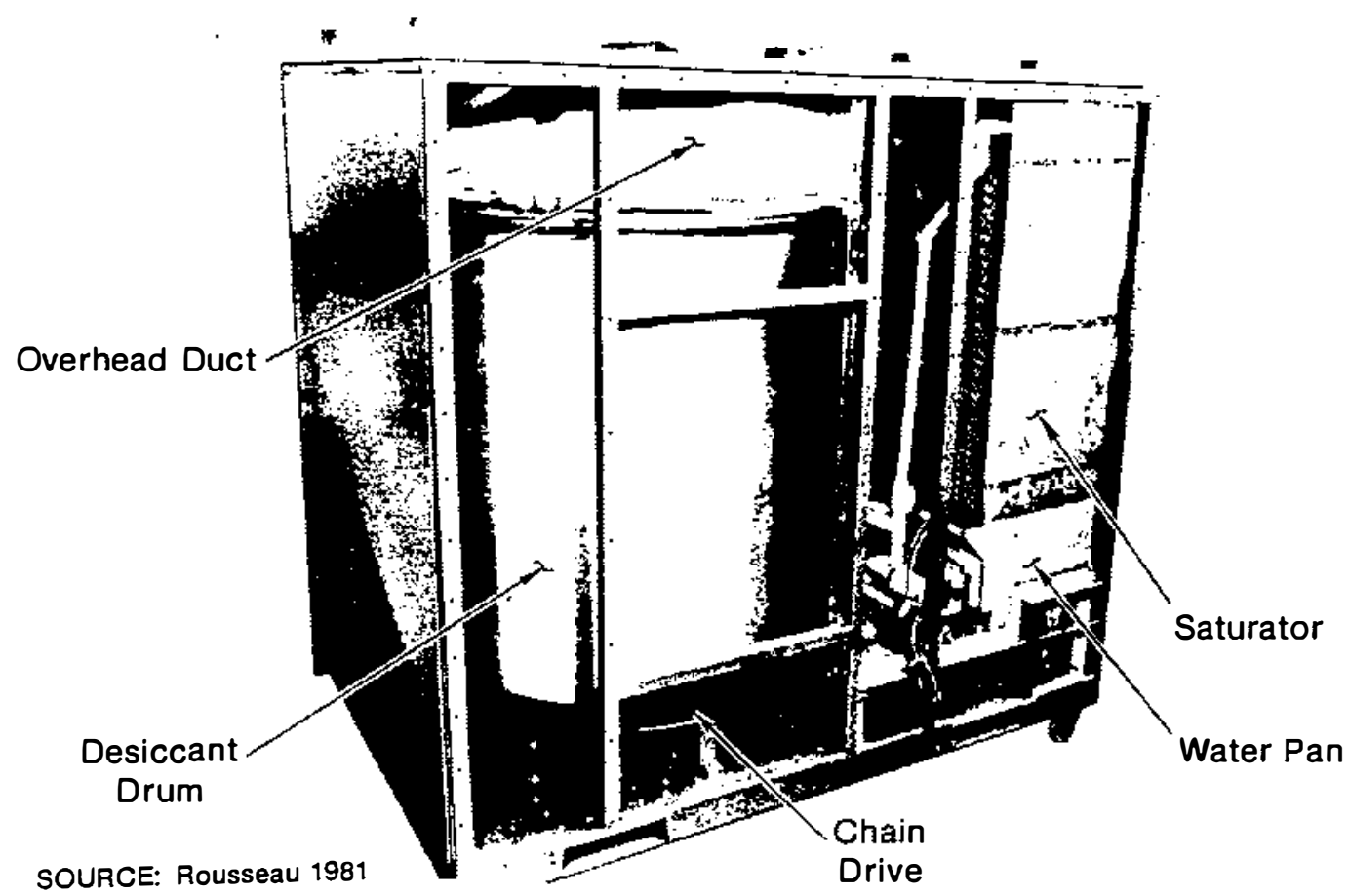

Figure 3-1. AfResearch Desiccant Cooling Syste 
Steel Screen,

$0.13-\mathrm{cm}(0.05-\mathrm{in}$.$) Holes on$

$0.21-\mathrm{cm}(0.081-\mathrm{in}$.)

Staggered Centers
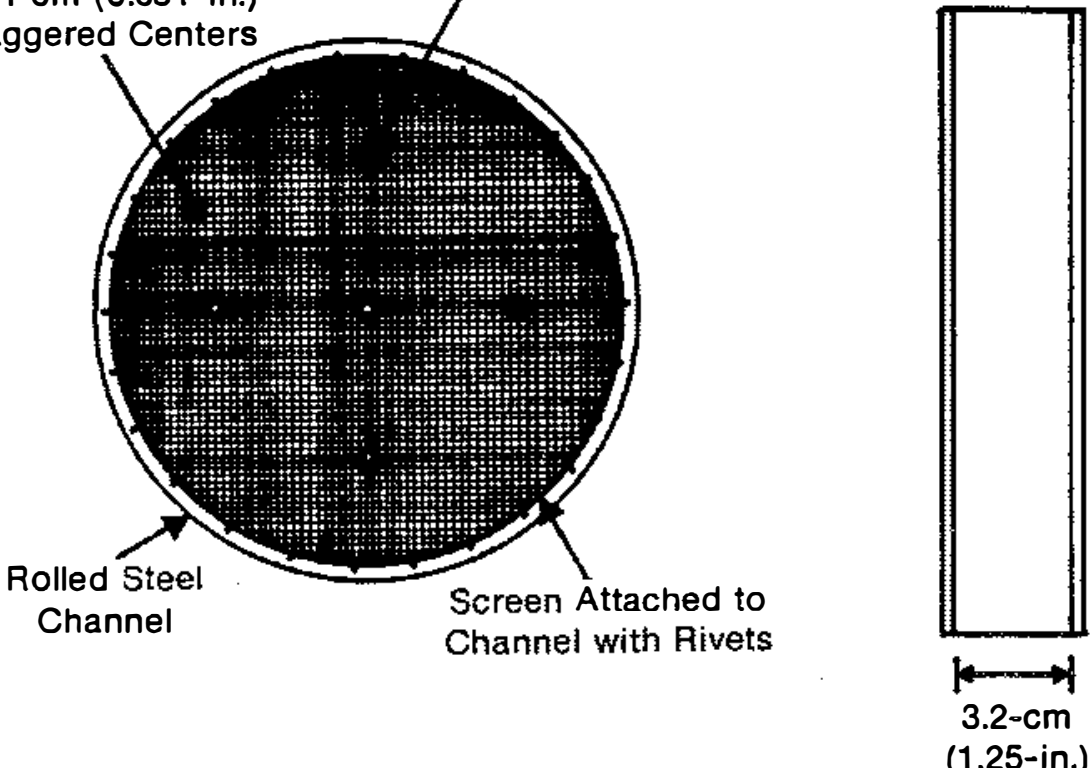

$\because \quad \overline{0}$

74-cm

(29-in.)

(1.25-in.)

\section{Figure 3-2. Silica Gel Test Bed}

In installing the test article, we tried various sealing configurations to minimize leakage around the edge of the bed. The sealing system chosen consisted of closed-cell foam attached inside the duct chamber around the perimeter of the bed. This yielded the highest pressure drop across the bed. Proper sealing was evident from the depression made in the foam by the edge of the bed.

Since the first test article was larger than the duct, transition sections were fabricated from sheet metal. To improve mixing and uniformity of flow, we installed a mixer and perforated plate on each side of the test article. Also, the pressure drop across the test bed itself was quite large [about $250 \mathrm{~Pa}$ (1-in. WG) at $170 \mathrm{~g} / \mathrm{s}$ (300 scfm)] and provided for good uniformity of flow.

In addition to testing the loop, we made nine experimental runs on the $74-\mathrm{cm}$ (29-in.) bed to validate SERI's in-house desiccant computer model, DESSIM. This code performs heat and mass transfer calculations using simple equations adapted from heat exchanger theory. Published experimental data on silica gel properties and transfer coefficients are used in calculating the properties of a control volume of air as it moves through bed segments. More details on DESSIM can be found in Barlow (1981).

Figure 3-3 is a psychrometric chart showing inlet air conditions for all the adsorption test runs. Both adsorption and desorption runs were made in accordance with the experimental procedure discussed earlier. Test conditions are also summarized in Table 3-1. An $A$ after a number indicates an adsorption run, and an $R$ indicates regeneration. 


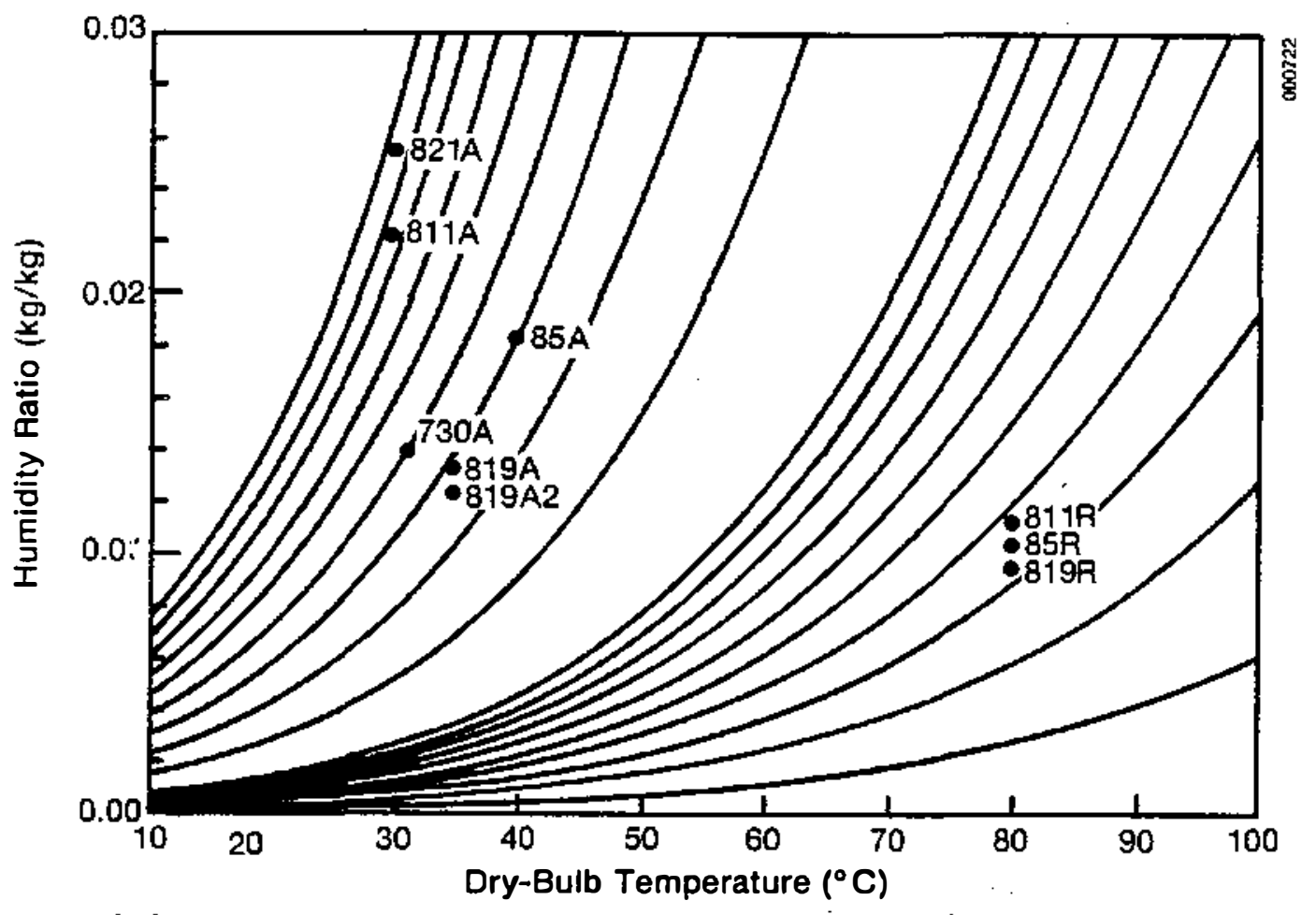

Figure 3-3. Psychrometric Chart Showng Inlet Air Conditions for the Experimental Runs

Table 3-1. Test Conditions for Desiccant Iaboratory Buns

\begin{tabular}{|c|c|c|c|c|c|c|c|}
\hline \multirow{2}{*}{ Run $^{2}$} & \multicolumn{3}{|c|}{ Inlet Conditions } & \multicolumn{2}{|c|}{$\begin{array}{l}\text { Predicted } \\
\text { Bed Water Content }\end{array}$} & \multicolumn{2}{|c|}{$\begin{array}{l}\text { Previous } \\
\text { Regeneration } \\
\text { Conditions }\end{array}$} \\
\hline & $\begin{array}{l}\text { Temp. } \\
\left(\mathrm{o}_{\mathrm{C}}\right)\end{array}$ & $\begin{array}{l}\text { Humidity } \\
(\mathrm{kg} / \mathrm{kg})\end{array}$ & $\begin{array}{l}\text { Alr Flow } \\
(\mathrm{kg} / \mathrm{s})\end{array}$ & $\begin{array}{l}\text { Inftial } \\
(\mathrm{kg} / \mathrm{kg})\end{array}$ & $\begin{array}{c}\text { Final } \\
(\mathrm{kg} / \mathrm{kg})\end{array}$ & $\begin{array}{l}\text { Temp. } \\
\left({ }^{\circ} \mathrm{C}\right)\end{array}$ & $\begin{array}{l}\text { Humidity } \\
(\mathrm{kg} / \mathrm{kg})\end{array}$ \\
\hline $730 \mathrm{~A}$ & 30.5 & 0.0138 & 0.212 & 0.0155 & $--b$ & 81.1 & 0.0073 \\
\hline $85 \mathrm{~A}$ & 40.0 & 0.0184 & 0.208 & 0.0195 & 0.178 & 80.0 & 0.0097 \\
\hline $85 R$ & 80.4 & 0.0107 & 0.246 & 0.178 & - & - & - \\
\hline $811 \mathrm{~A}$ & 29.2 & 0.0226 & 0.208 & 0.021 & 0.333 & 79.8 & 0.0107 \\
\hline $811 R$ & 79.7 & 0.0112 & 0.252 & 0.333 & $\rightarrow$ & -- & - \\
\hline 819A & 35.6 & 0.0134 & 0.227 & 0.0203 & 0.170 & 80.4 & 0.0105 \\
\hline $819 R$ & 80.7 & 0.0103 & 0.246 & 0.170 & 0.0198 & - & - \\
\hline 819A2 & 35.5 & 0.0126 & 0.227 & 0.0198 & 0.163 & - & - \\
\hline $82 \mathrm{~A}$ & 30.0 & 0.0267 & 0.212 & 0.0246 & -- & 60.4 & 0.0141 \\
\hline
\end{tabular}

a Suffix: $A=$ adsorption, $R=$ regeneration.

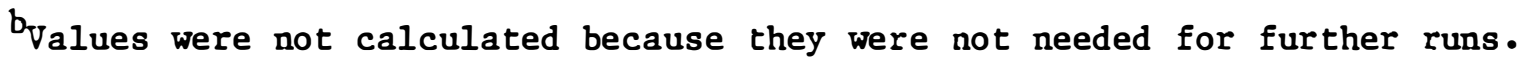


Results of the tests are shown graphically in Figs. 3-4 through 3-12. The figures each contain three plots showing outlet air temperature versus time, outlet humidity ratio versus time, and a process line for the outlet air on a psychrometric chart where I indicates inftial outlet state and $F$ is the final outlet state. In each case, the circles represent experimental data and the solld line represents computer model (DESSIM) predictions. Each plot also indicates which value for the Lewis number was used in the model, as well as which correlation was used for silica gel equilibrium isotherm data.

The adsorption/desorption process involves coupled heat and mass transfer. During adsorption or desorption, two waves propagate through the desiccant bed; both are coupled thermal and molsture waves. The first adsorption wave travels faster and is similar to a pure thermal wave in that the temperature of the desiccant bed changes significantly with its passing, while the moisture content of the desiccant changes only slightly. The second wave moves more slowly and is often referred to as the molsture wave. The second wave is also a result of coupled heat and mass transfer, and desiccant temperature and molsture content change simultaneously with its passing. The progression of these two waves past the outlet end of the desiccant bed is reflected by the progression of the outlet air states along a psychrometric process path. The path traced by outlet alr states during elther adsorption or desorption has two legs, one assoclated with each of the two waves. The leg assoclated with the first wave has a trajectory similar to that of a line of constant relative humidity on a psychrometric chart. The leg associated with the second wave is simflar to a line of constant enthalpy. [A detailed description of the physical behavior of desiccant beds is found in Barlow (1981), and only the major points will be discussed here.]

Because of restrictions on parasitic power, the desiccant beds used in cooling systems and tested in the SERI facility are quite thin. To understand the experimental results for these thin beds, we focus on two runs: an adsorption run and a desorption run. With the thin test bed, the first wave passes quickly; only the effects of the second wave are demonstrated clearly in these runs.

\subsection{ADSORPTIOR}

Adsorption run $730 \mathrm{~A}$ was done with an inlet air temperature of $30.5^{\circ} \mathrm{C}\left(87^{\circ} \mathrm{F}\right)$, an inlet air humidity ratio of 0.0138 , and a dry-air flow rate of $212 \mathrm{~g} / \mathrm{s}$ (373 scfm). Before that run, the desiccant bed was regenerated to a molsture content of about $2 \%$ by welght using regeneration air at $81^{\circ} \mathrm{C}\left(178^{\circ} \mathrm{F}\right)$ with a humidity ratio of 0.0073 .

Figure 3-4(b) shows the outlet alr humidity ratio versus time during run 730A. This is the so-called breakthrough curve. In a deeper bed, the outlet humidity ratio would remain low for some time until the adsorption wave broke through; then the humidity ratio would begin to rise. In this case, however, the packed silica gel bed is actually thinner than the theoretical mass transfer zone (MTZ), and molsture begins to break through very early in the run. As the run continues, the remaining bed capacity continues to drop, and the exit air humidity increases as the adsorption wave exits. Agreement between the computer model predictions and measured humldity ratios (derived from the 

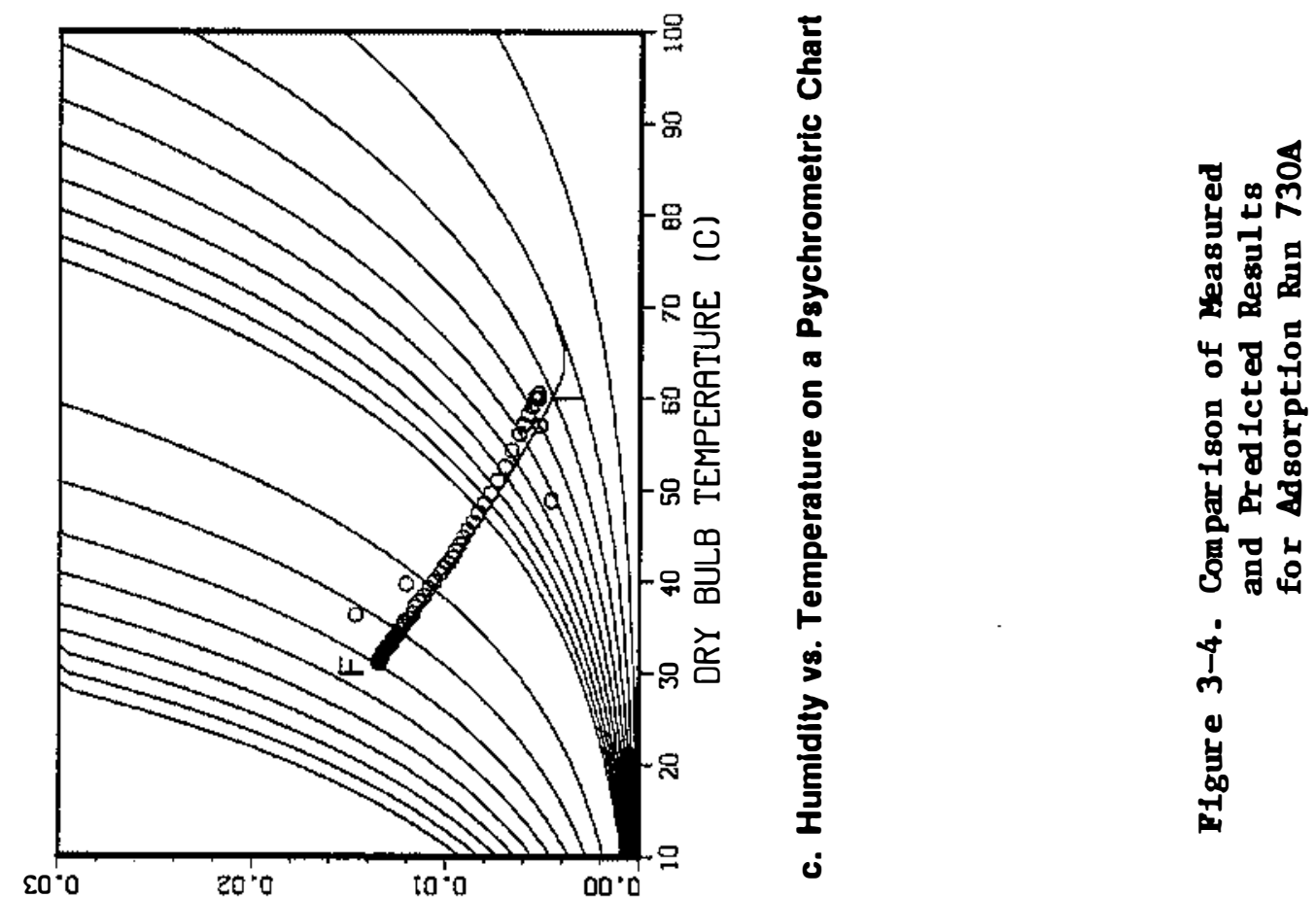

(פX/פX्र) OIIUل RIIOIWחH
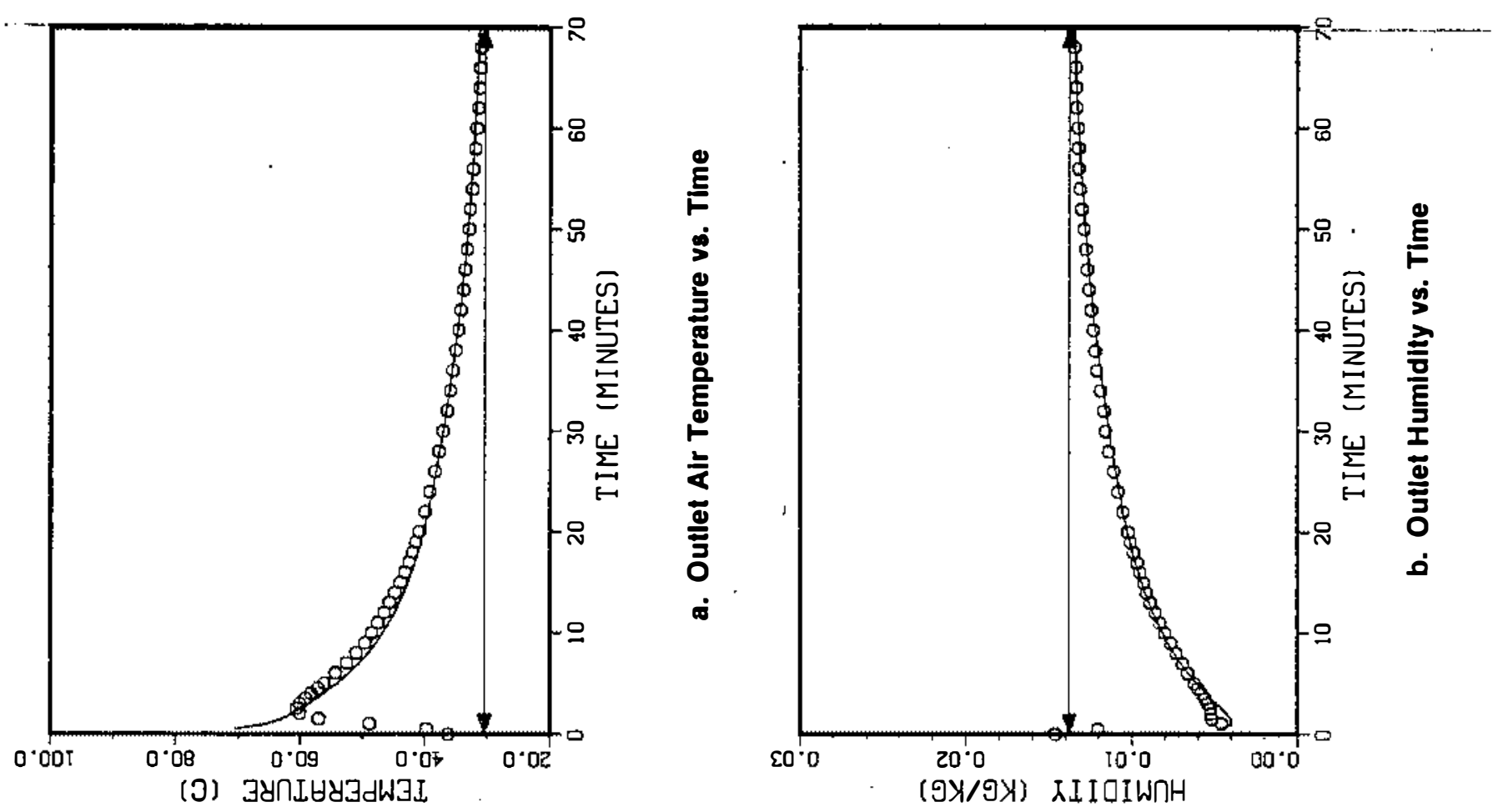


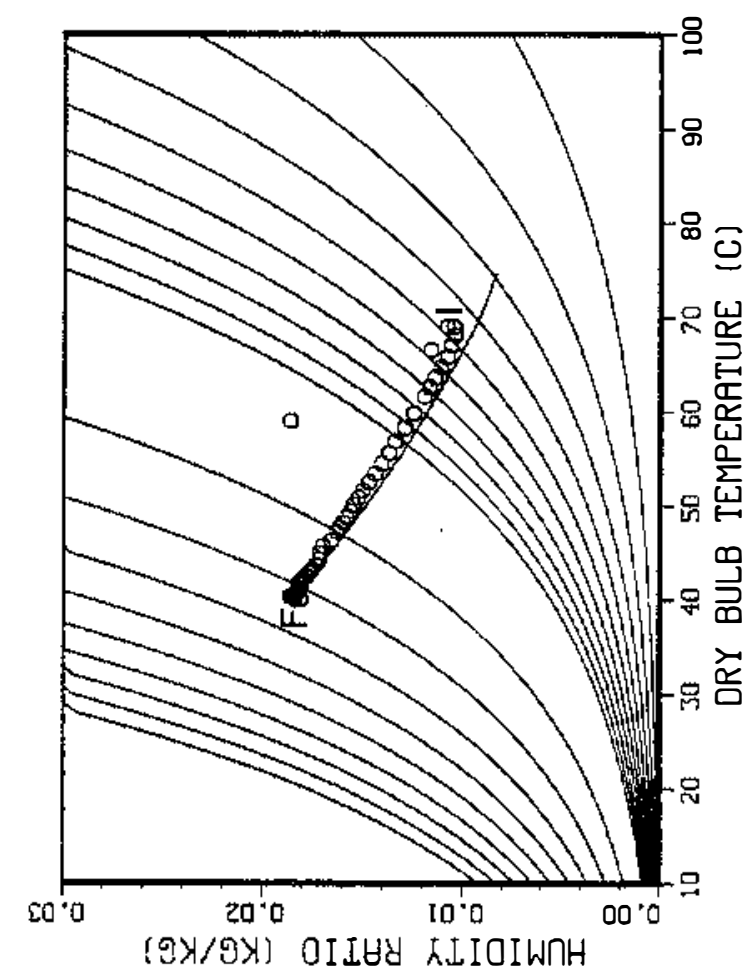

눙

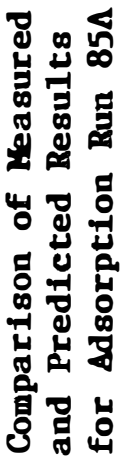

ñ
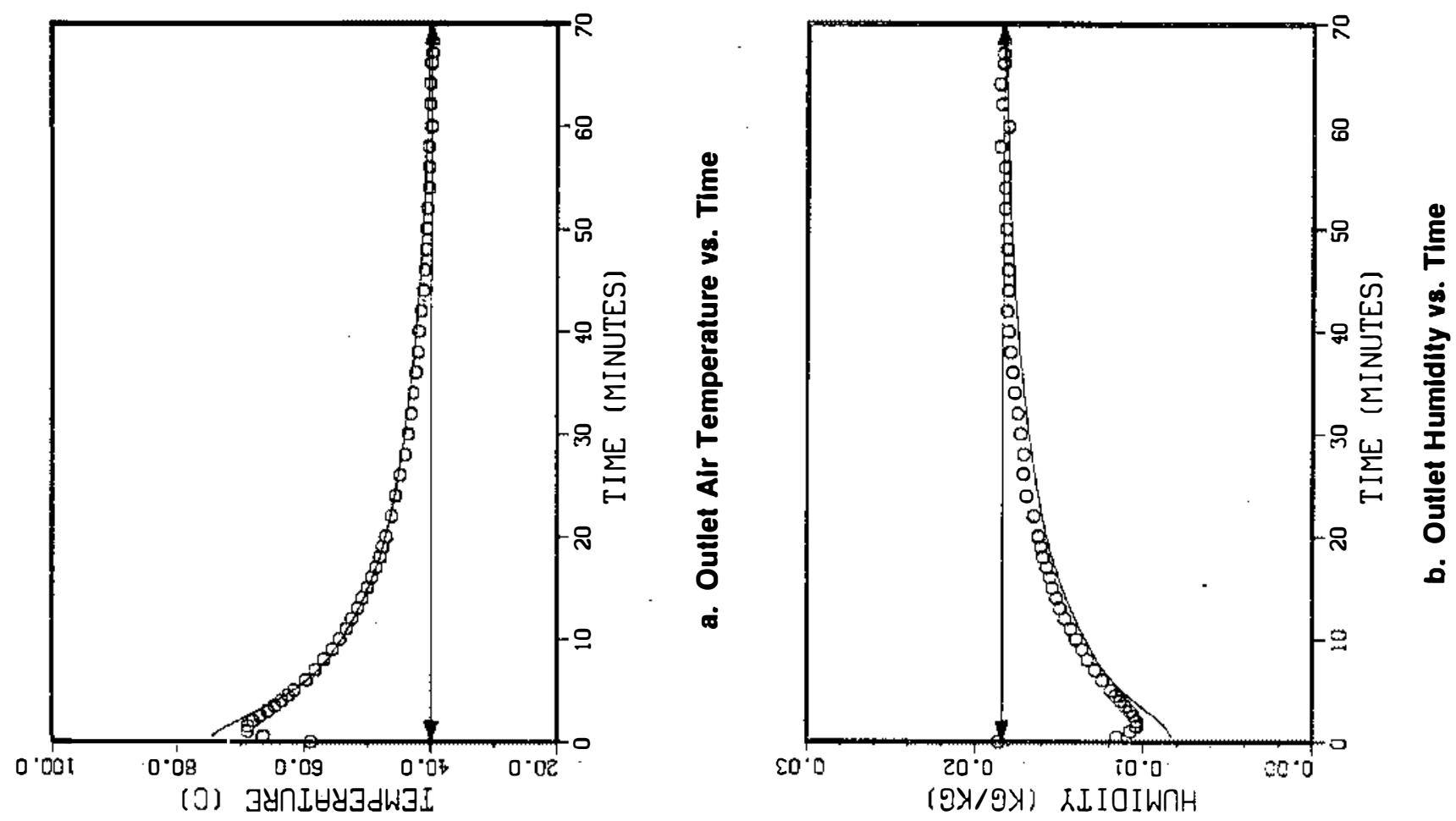

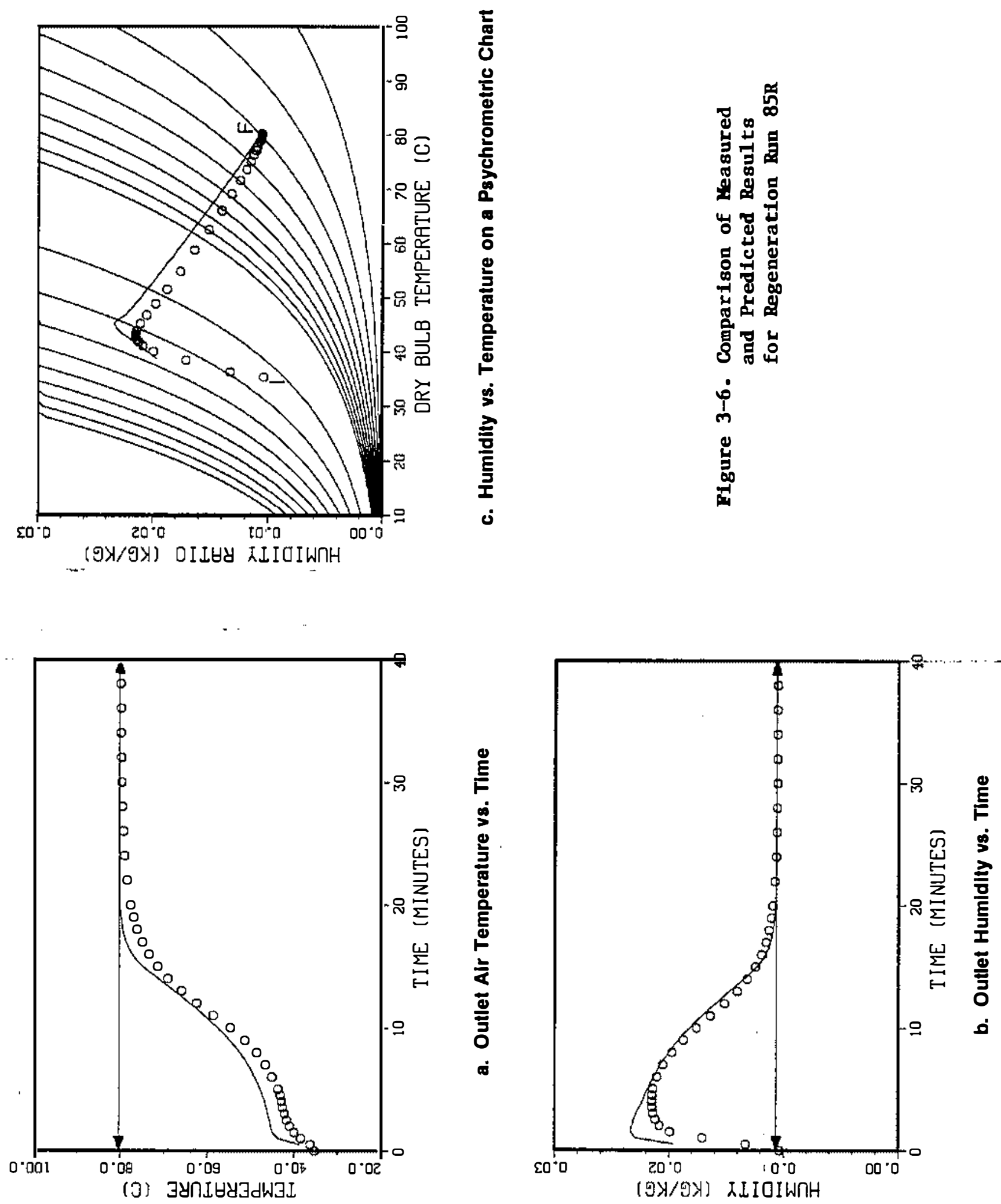


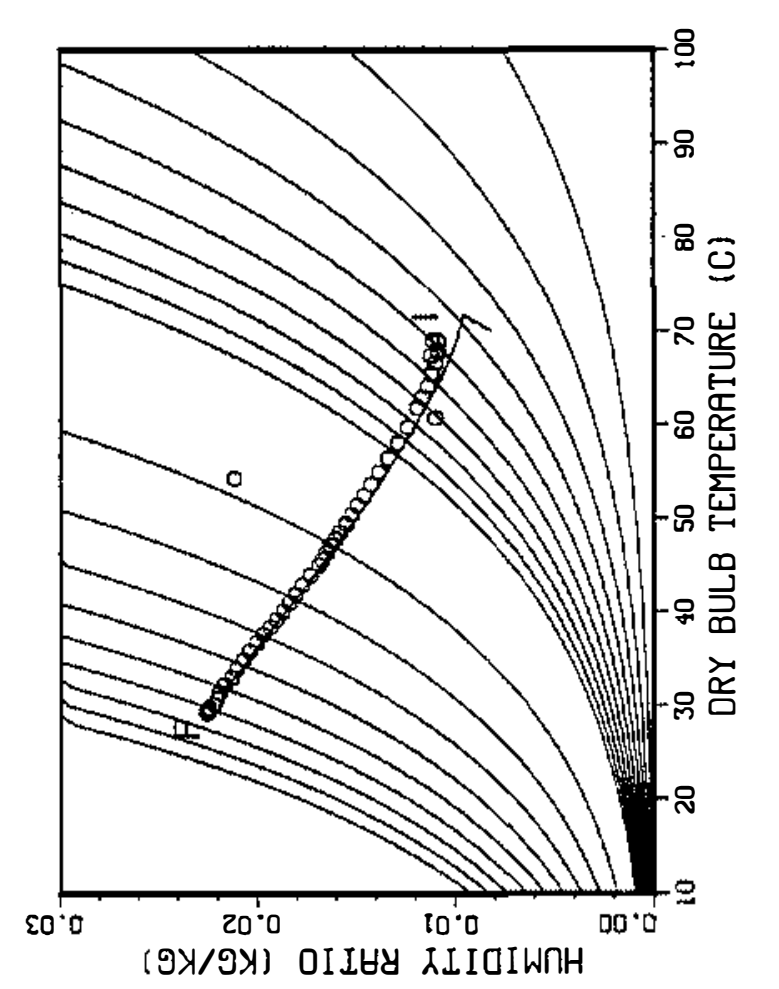

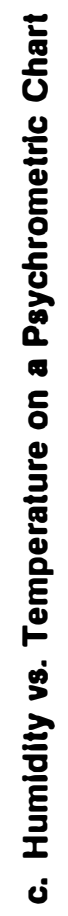
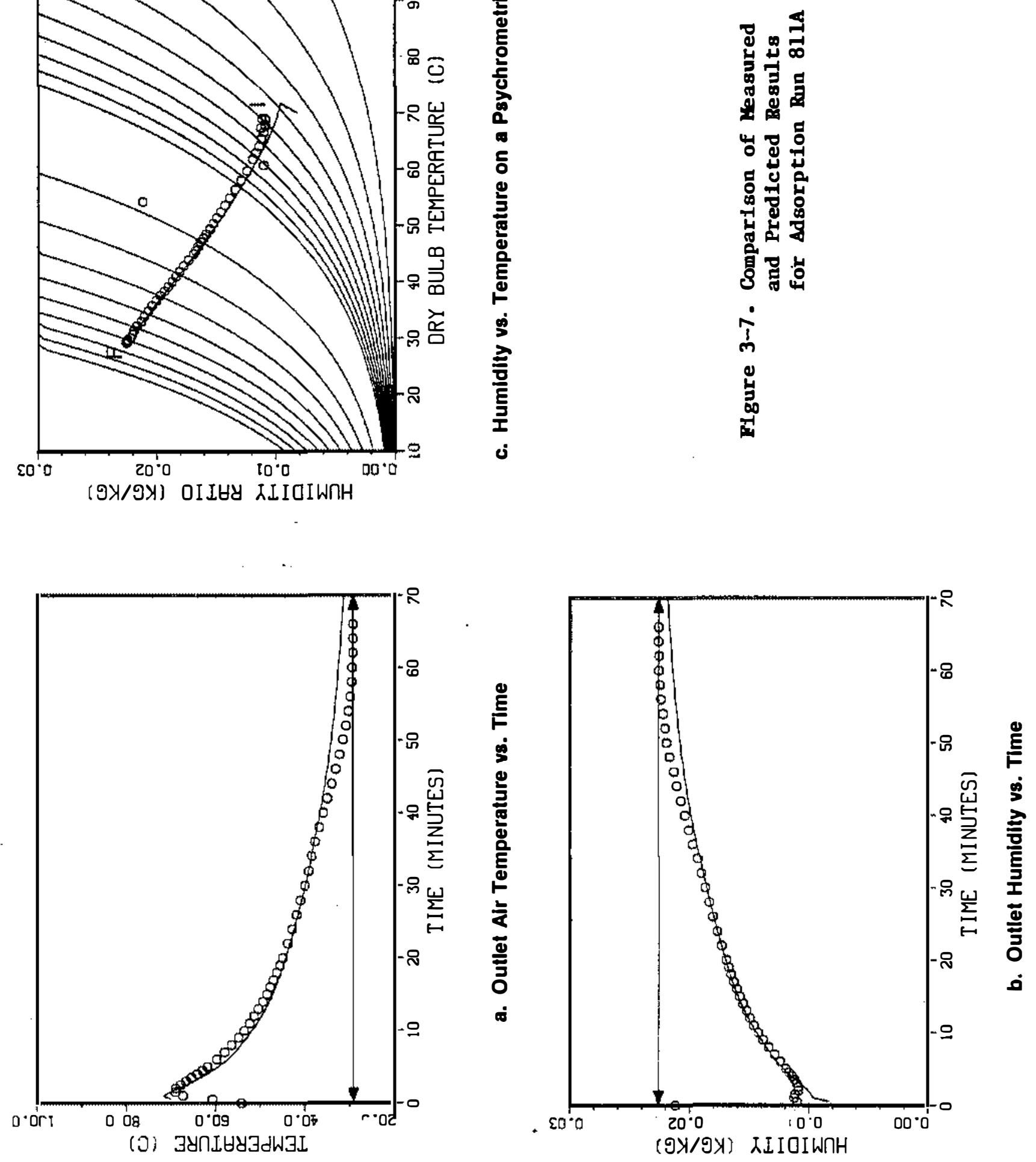


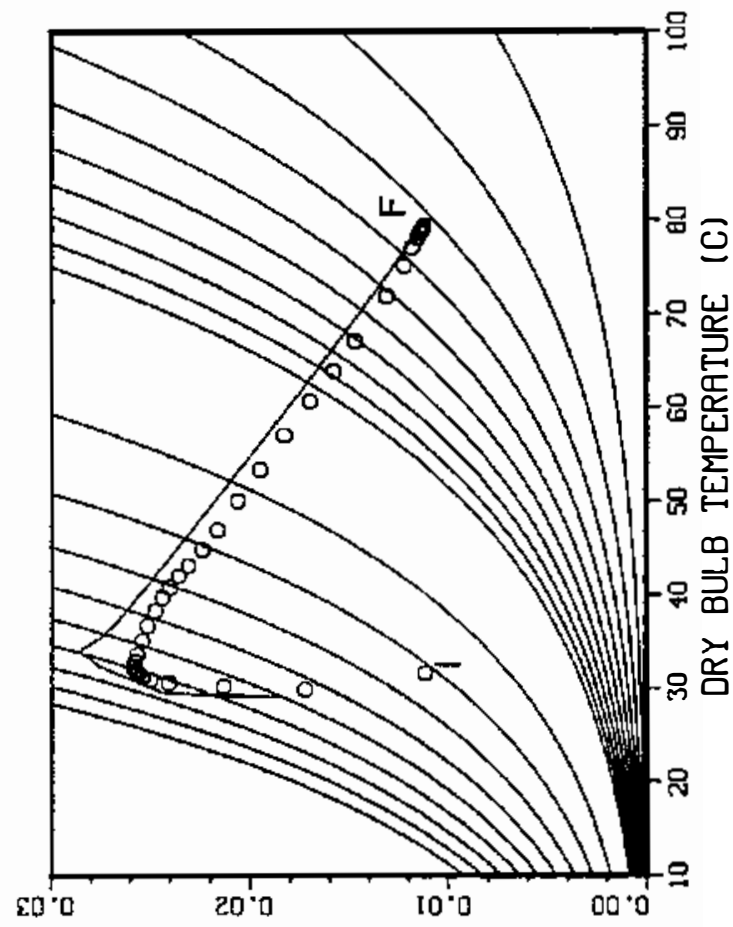

(ЭX//9X) OI IUY XLIOIWกH
눙

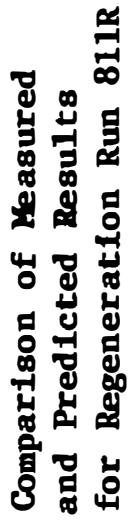

$\dot{m}$

嵌

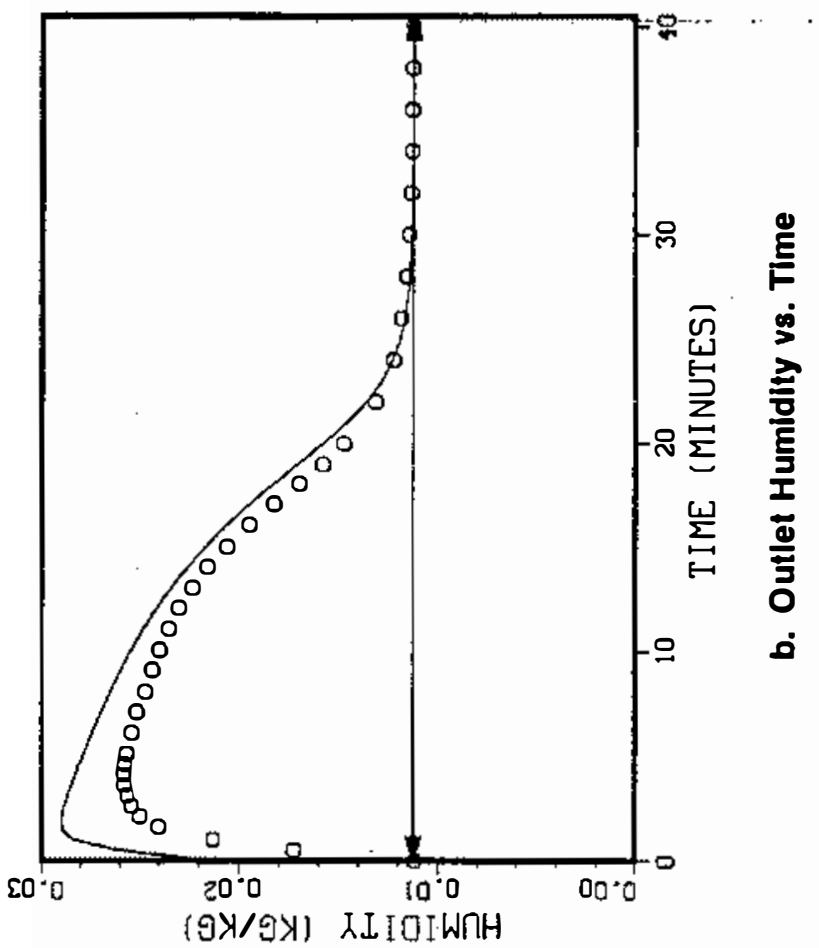




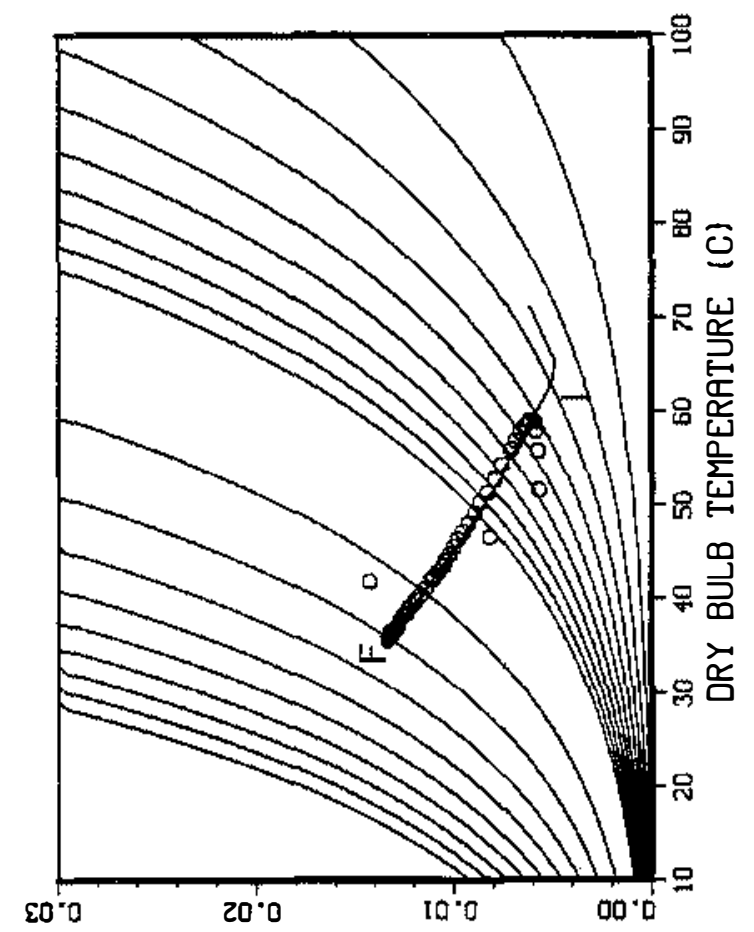

(פX/9X) OILUY XIIUIWกH

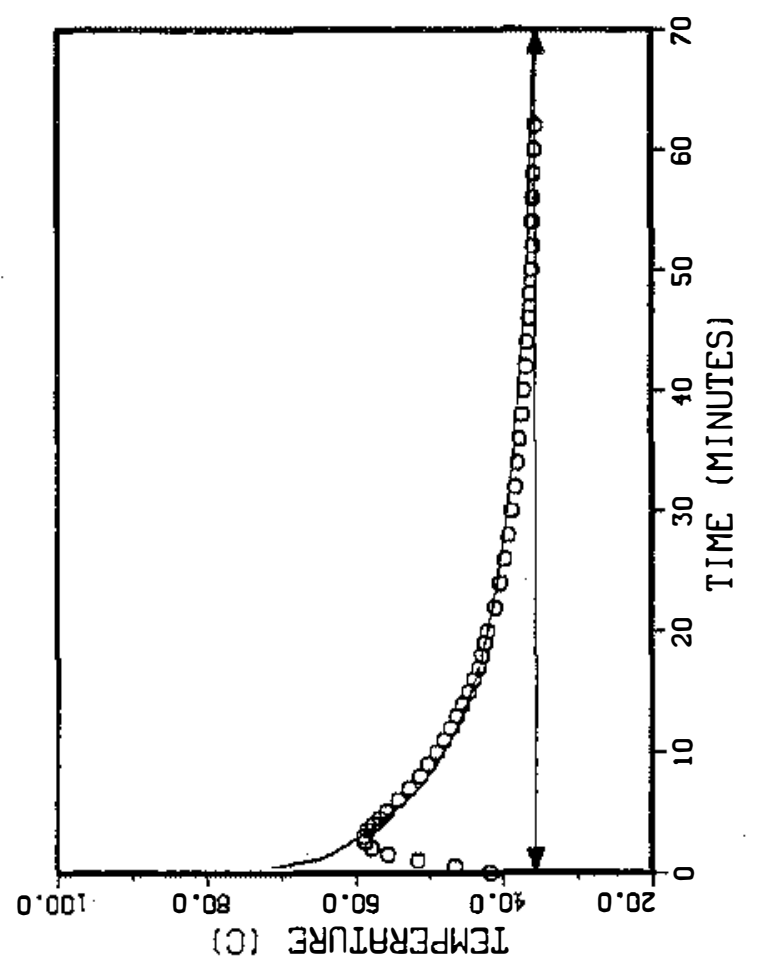

ํㅗㅇ
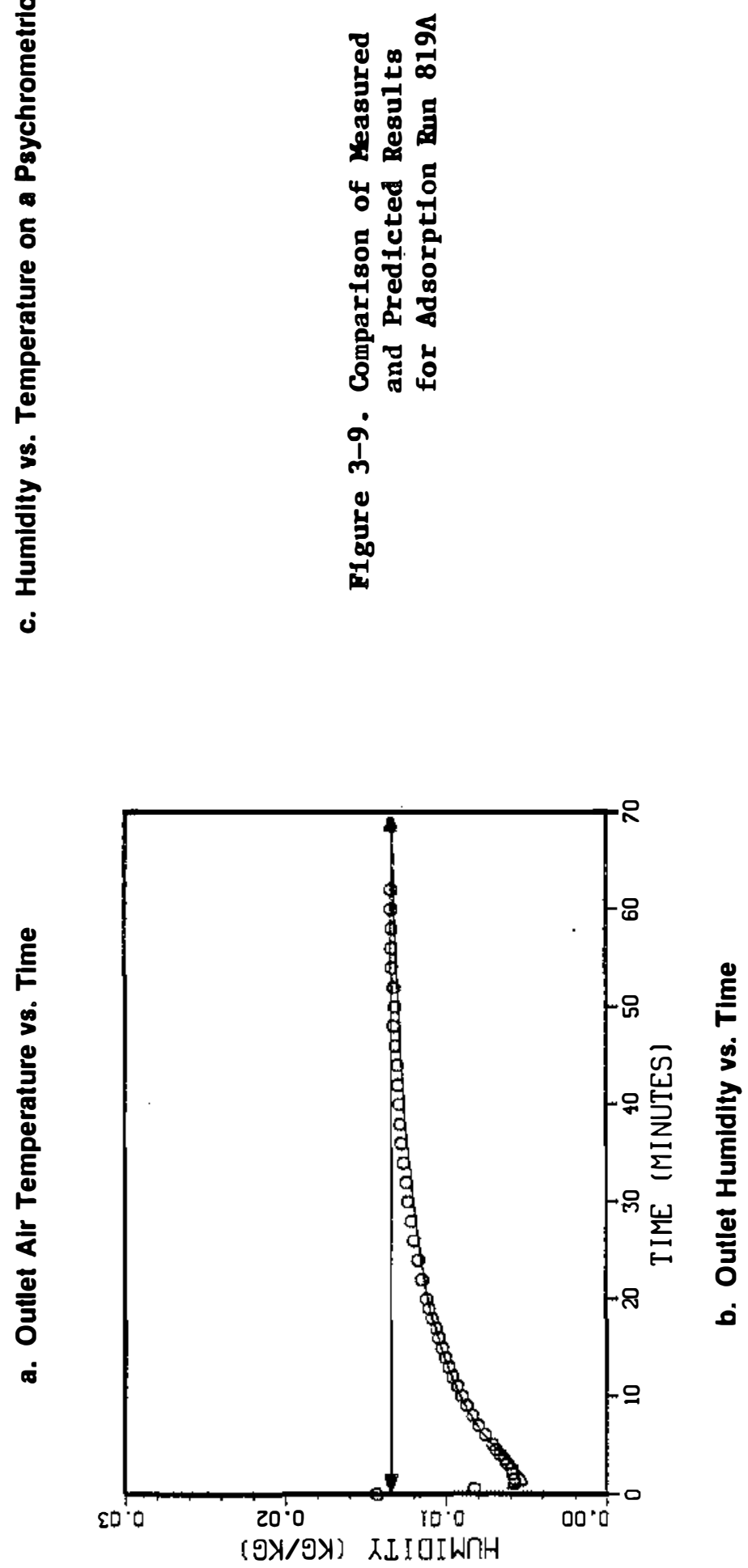


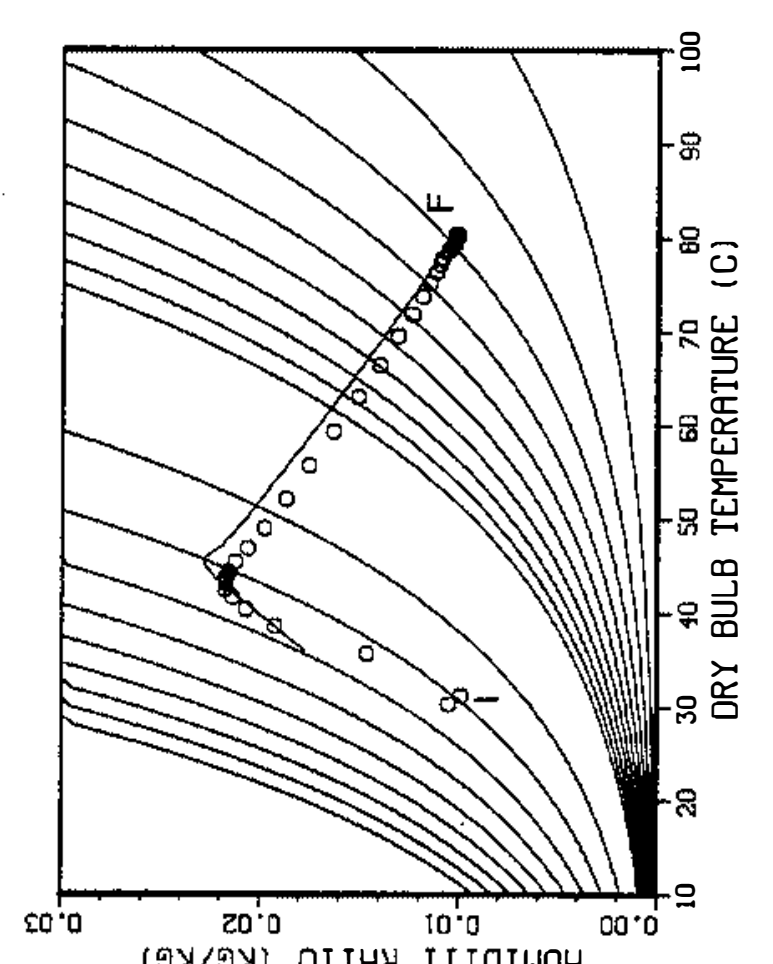

(9X/פ) OIIHY LIIOIWกH

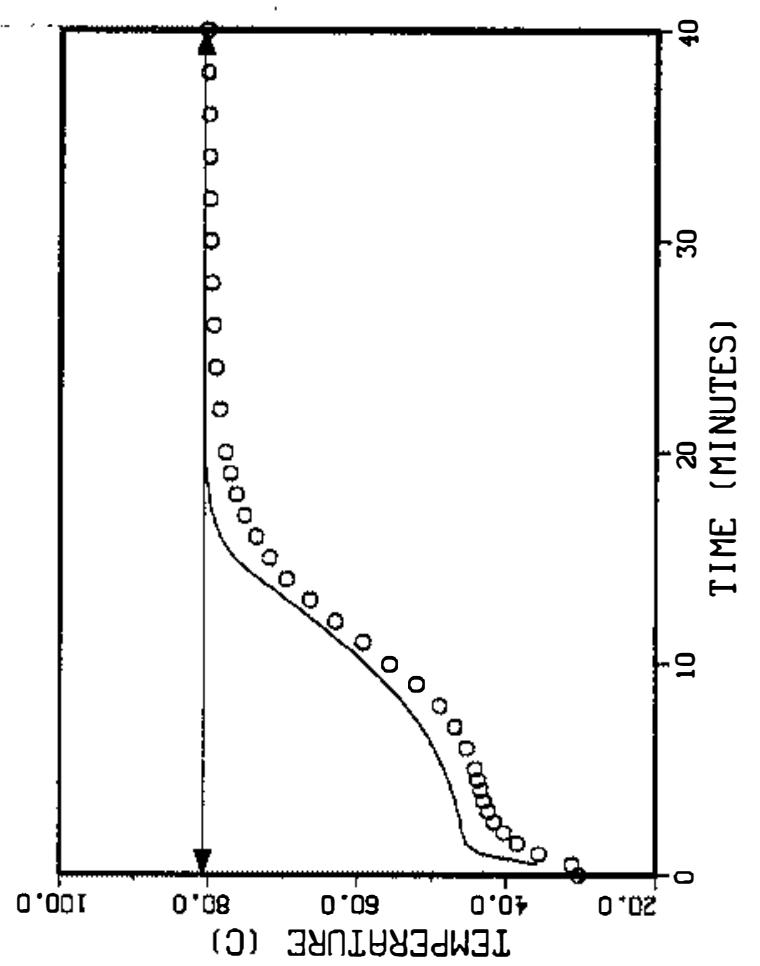

ปั

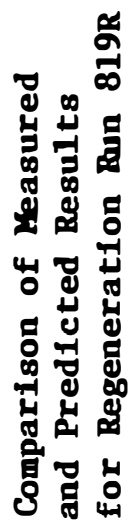

号

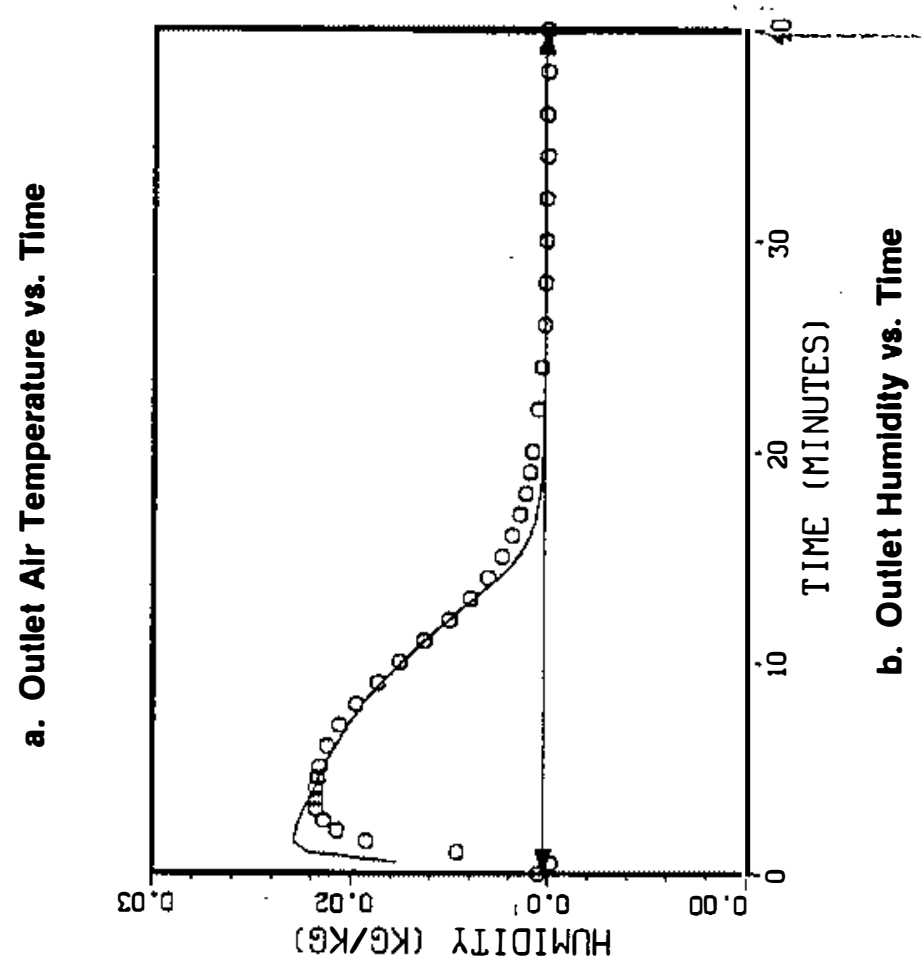




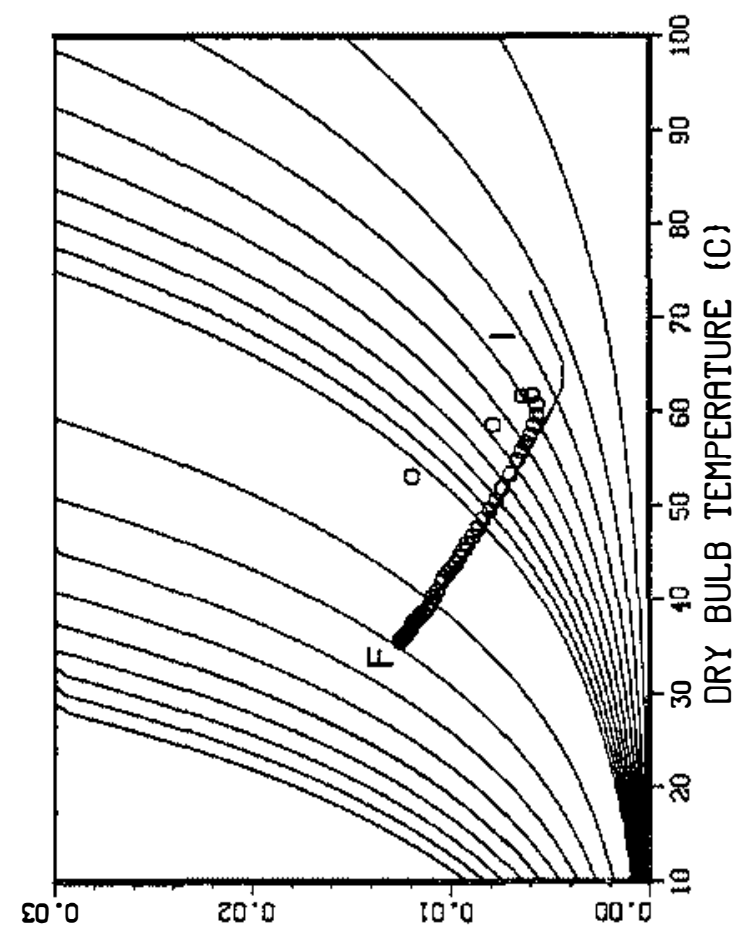

(פX/פX) OIIUY RLIOIWחH

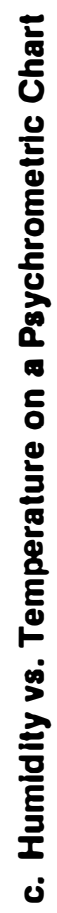

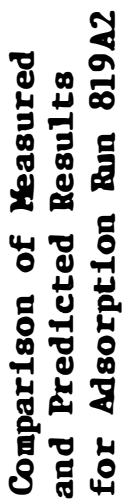

年

包
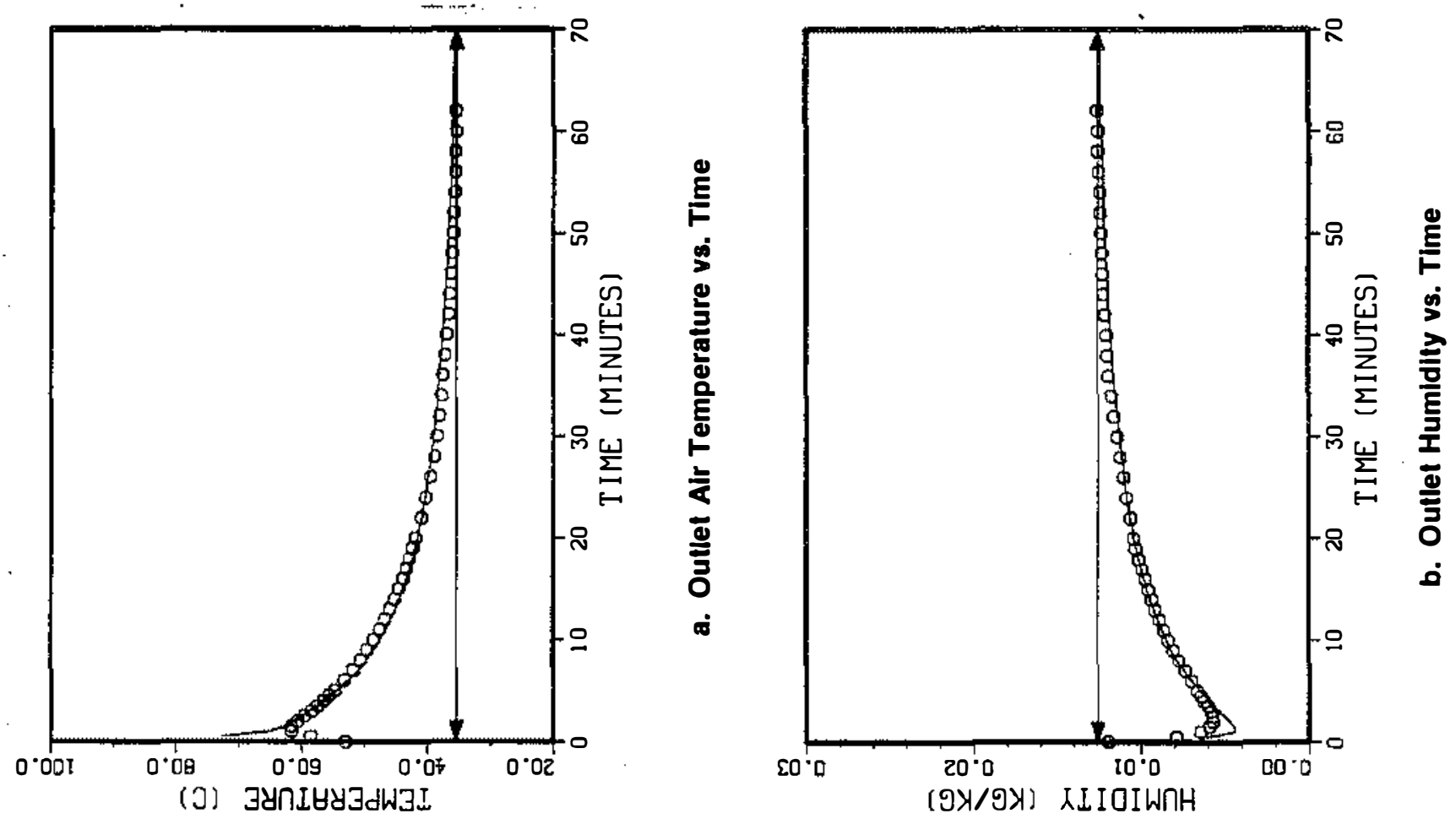

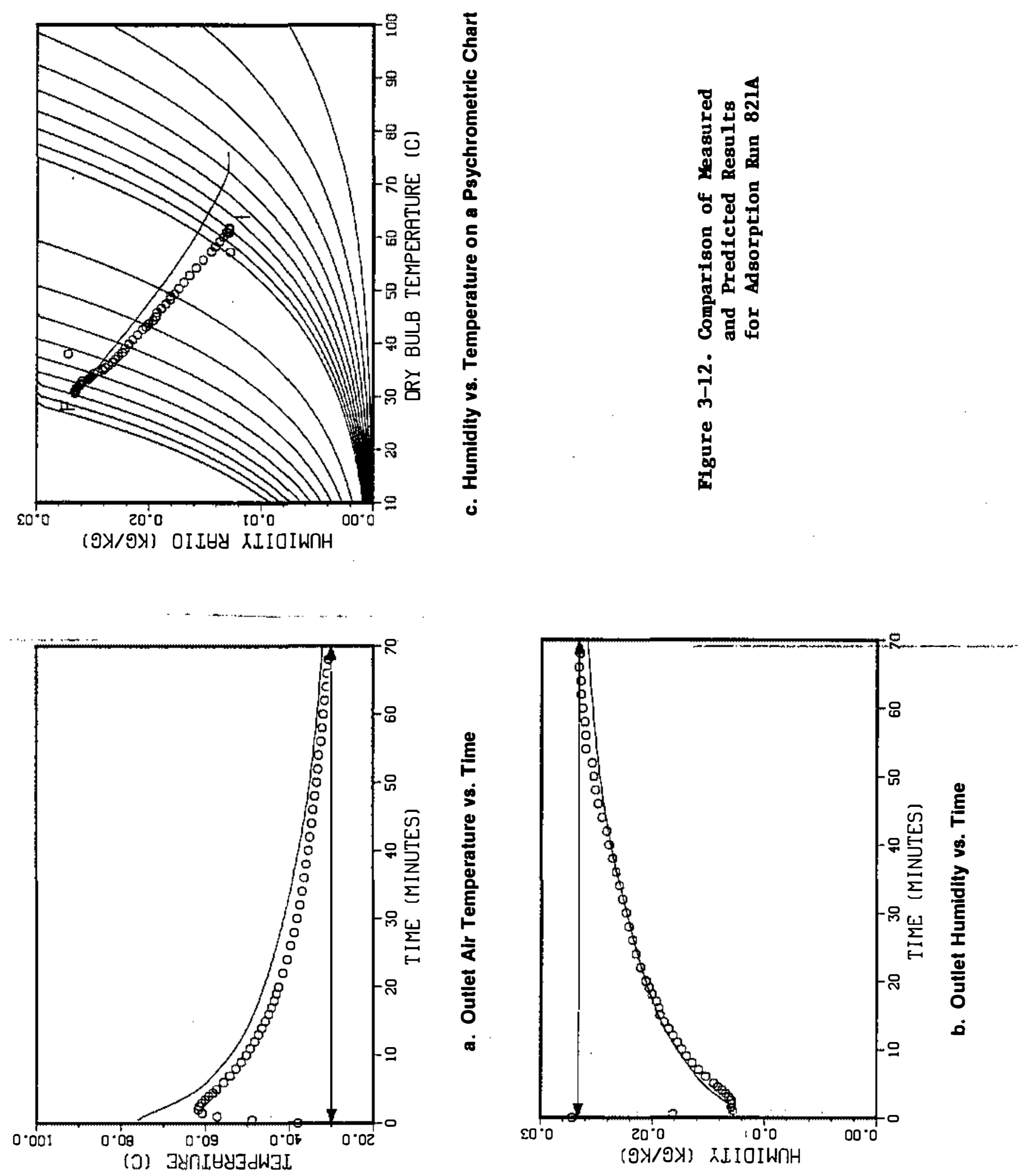
measured dew point) is very close, except during the first one or two minutes of the run. This discrepancy does not seem to be the result of error in the computer model, however. Rather, we belleve it results from the response characteristics of the optical dew-point hygrometers and their sampling lines, and from the fact that the thermal capacitance of the screens is not included in the computer model.

The outlet air temperature versus time for run $730 \mathrm{~A}$ is shown in Fig. 3-4(a). The measured outlet air temperature rises rapidly for the first two minutes of the run, while the predicted outlet temperature starts high and falls for the first two minutes. These rapid changes correspond to the passing of the first wave through the bed. Measured and predicted results are different because the prediction was carried out assuming that the initial bed temperature was the same as the regeneration temperature previously used to regenerate the bed. Because of the delay between regeneration and adsorption runs, the desiccant bed was able to cool down, and the measured temperature of the air that left the bed first was below $40^{\circ} \mathrm{C}$. Other simulations have demonstrated that the inlet temperature of the bed has essentially no effect on the predicted result after the passing of the first wave.

In this adsorption run, humid air passes through a dry and relatively cool desiccant bed. As the air first enters the bed, mo isture is adsorbed by the desiccant. The adsorption process releases energy (the heat of adsorption), which raises the local temperature of the bed and the air. This hot, dry air then progresses through the bed and begins to heat the bed. This effect is what produces the first wave during adsorption. The temperature of the air that first leaves the bed is the same as the initial temperature of the bed. As the first wave passes through the bed, the outlet temperature changes rapidiy; in this case rising. Then, the outlet temperature slowly decays toward the inlet air temperature as the broad second wave works its way through the bed. As the bed picks up water, less adsorption takes place, less heat is produced, and there is a corresponding drop in outlet dry-bulb tempera ture.

Figure 3-4(c) shows measured and predicted outlet air states on a psychrometric chart for adsorption run 730A. Outlet states move from lower right to upper left on a psychrometric process line, from a hot, dry state toward the state of the inlet air. The outlet air reaches the inlet state when the second wave has passed completely through the bed and the entire bed is in equilibrium with the inlet air. Again, agreement between measured and predicted results is close, except during the first two minutes. The dehumidification line (or process line for the second wave) differs from a constant enthalpy line by the difference between the heat of condensation and heat of adsorption; thus, it has a shallower slope. If we choose any point on that line, the air flowing through the bed at that time moves down the dehumidification line to the point that would be the exit condition at that time. Since the heat of adsorption is greater than the heat of condensation, the air exits the bed with greater enthalpy than it had on entering the bed.

In all three of the graphs of Fig. 3-4, only the effects of the second adsorption wave are demonstrated clearly, because the first wave travels through a thin bed of this type very rapidly. The effects of the first wave are discussed in Barlow (1981), where predictions are compared with published data on adsorption/desorption in thicker beds of silica gel. 


\subsection{REGBNERATION}

Case $85 \mathrm{R}$ was a regeneration run with an inlet dry-bulb temperature of $80.4^{\circ} \mathrm{C}$, inlet humidity rat1o of 0.0107 , and dry air flow rate of $246 \mathrm{~g} / \mathrm{s}$ (see Table 3-1). As with the adsorption case, the outlet temperature, outlet humidity, and psychrometric process lines are plotted (see Figs. 3-6a,b,c).

Figure 3-6b shows the outlet air humidity versus time. This graph is not, as one might suspect, symmetric with the adsorption case but rather rises for several minutes before decreasing, as a result of the first wave passing through the bed. Since the bed is relatively cool after adsorption, it gives up more and more moisture as it is heated (up to $80^{\circ} \mathrm{C}$ ). This is shown clearly by the well-defined leading edge of the psychrometric chart (F1g. $3-6 \mathrm{c}$ ).

Ideally, the line that defines the first wave would be close to a constant relative humidity line, since this represents a primarily thermal wave with little change in the molsture content of the bed. (The equilibrium vapor pressure of silica gel can be described falrly well as a function of relative humidity.) In actuality, the process line must deviate somewhat from a constant relative humidity line to permit a change in the bed molsture content, which, in turn, allows for a change in the alr molsture content. Also, since the bed has heat capacity, the first wave process line tends to be steeper than a constant relative humidity line. As mentioned, the second process line is close to an adlabatic process and differs from a constant enthalpy line by the difference between the heat of adsorption and heat of condensation.

The plot of the outlet humidity ratio versus time shows that the second wave is sharper than it would be for an adsorption run; 1.e., the wave is narrower. (Note that an expanded time scale is used for the regeneration plots.) This occurs because the local adsorption wave speed in the bed decreases as the wa ve passes, causing the second wa ve front to spread. During desorption, however, the local wave speed increases as the wave passes, which results in a sharper second wave front. This effect is discussed further in Barlow (1981).

The outlet air temperature versus time also shows the effect of the first wave. The first air passing through the bed is cooled by the gel, but the exit temperature increases rapidly as the bed becomes heated and less and less of it is available for cooling. Once equilibrium is reached, a large bed would show constant outlet temperature. In this thin bed, however, the mass transfer zone begins to break through quickly, and the second wa ve shows up immediately after the first wave ends. Note that the process line for regeneration has the same slope as it does for adsorption. In the regeneration case, the lower right end of the line represents the condition of inlet air. The alr passing through the bed moves up the process line and exits at some condition on that line. The exit conditions along the line move from upper left to lower right, just the opposite of that for the adsorption case.

Because the adsorption/desorption process involves both heat and mass transfer, 1dentifying the proper transfer coefficlents to be used in predictions is critical. Heat transfer coefficlents in packed beds have been characterized fairly well, and a standard correlation is used in the computer model. Mass transfer coefficlents for adsorption in packed beds have not been well 
characterized, because a resistance to mass transfer exists within the solid particles as well as in the air stream. In adsorption modeling, the gas-side transfer coefficient is modified to account approximately for the solid-side resistance.

For the predictions reported here, the mass transfer coefficient is obtained from $g=h / C_{p}$ Le, where $h$ is the heat transfer coefficient, $C_{p}$ is the specific heat of air, and Le is an effective Lewis number. Recent theoretical work by van Leersum (1981) has indicated that an effective Lewis number between 3 and 4 is appropriate for rotary dehumidifiers in desiccant cooling systems. A Lewis number of 3 worked well for adsorption predictions but did not work well for desorption. To obtain a reasonable fit to desorption data, the effective Lewis number had to be increased to 9 .

This value was used for all the regeneration predictions reported here. This is a significant result in that it suggests that the re is a dynamic hysteresis effect in silica gel properties. That is, it is harder to get water out of silica gel particles than it is to get water in. Consequently, it may not be possible to use a single diffusion coefficient to describe transport of water within silica gel particles during both adsorption and desorption. To our knowledge, this effect in silica gel has not yet been documented, even though previous investigators have had difficulty matching predictions with data for desorption.

\subsection{PRESSURB DROP MRASUREMENTS}

Fan power requirements are very important in the design of a desiccant cooling system; thus, the pressure drop across the bed was determined as a function of flow rate. Results for the $74-\mathrm{cm}\left(29-1 \mathrm{n}_{\text {.) }}\right.$ bed are given in Table 3-2. A typical face velocity for a desiccant system is $0.33 \mathrm{~m} / \mathrm{s}(65 \mathrm{ft} / \mathrm{min})$, which would correspond here to roughly $170 \mathrm{~g} / \mathrm{s}$ (300 scfm). At this flow, the pressure drop was approximately $225 \mathrm{~Pa}$ ( 0.9 in. WG).

Table 3-2. Pressure Drop 08. Flov Rate for 74-cin Dianeter, 3.2-cm Deep SIllca Gel (8-10 Mesh) Bed

\begin{tabular}{|c|c|c|c|c|c|c|c|}
\hline \multicolumn{2}{|c|}{ Flow Rate } & \multicolumn{2}{|c|}{$\Delta \mathrm{P}$} & \multicolumn{2}{|c|}{ Flow Rate } & \multicolumn{2}{|c|}{$\Delta \mathrm{P}$} \\
\hline $\mathrm{kg} / \mathrm{s}$ & $\operatorname{scfm}$ & $\mathrm{Pa}$ & in. WG & $\mathrm{kg} / \mathrm{s}$ & scfm & $\mathrm{Pa}$ & in. IV \\
\hline 0.116 & 204 & 137 & 0.552 & 0.235 & 415 & 387 & 1.555 \\
\hline 0.129 & 228 & 160 & 0.642 & 0.249 & 440 & 413 & 1.658 \\
\hline 0.143 & 252 & 182 & 0.730 & 0.263 & 464 & 449 & 1.805 \\
\hline 0.156 & 276 & 210 & 0.844 & 0.277 & 489 & 484 & 1.945 \\
\hline 0.169 & 298 & 236 & 0.948 & 0.290 & 512 & 519 & 2.085 \\
\hline 0.182 & 321 & 261 & 1.047 & 0.303 & 535 & 561 & 2.255 \\
\hline 0.196 & 345 & 288 & 1.157 & 0.316 & 558 & 593 & 2.380 \\
\hline 0.209 & 368 & 321 & 1.288 & 0.327 & 576 & 642 & 2.580 \\
\hline 0.222 & 391 & 353 & 1.418 & & & & \\
\hline
\end{tabular}


The pressure drop across the bed is the sum of pressure drops across the gel and across the two screens holding the gel in place. To determine the pressure drop across the gel alone, we cannot simply measure the $\Delta \mathrm{P}$ across an empty bed and subtract, because the screen pressure drop is much greater when it is installed in the bed because silica gel particles plug the screen holes. To determine this effect, small, 30-cm(12-in.)-diameter test sections were tested at two different lengths: $3 \mathrm{~cm}(1-3 / 16 \mathrm{ln} \cdot)$ and $10 \mathrm{~cm}$ (4 in.). (These sections were bullt in varlous lengths up to $20 \mathrm{~cm}$ ( 8 in.) to permit future testing of packed beds and with lengths exceeding that of the mass transfer zone.) At a given flow rate, the pressure drop across an installed screen can be determined algebralcally from the two total $\Delta P$ readings, as follows. If $\Delta \mathrm{P}_{\mathrm{s}}$ is the pressure drop across a screen, $\Delta \mathrm{P}_{1}$ is the pressure drop across the $3-\mathrm{cm}$ bed, and $\Delta \mathrm{P}_{2}$ is the drop across the 10-cm bed, we have

$$
\begin{aligned}
\Delta P_{1} & =2 \Delta P_{S}+\Delta P_{1-G E L} \\
\Delta P_{2} & -2 \Delta P_{S}+\Delta P_{2-G E L} \\
\Delta P_{2-G E L} & =\frac{0.102}{0.030}{ }_{2} \Delta P_{1-G E L}=3.368 \Delta P_{1-G E L}
\end{aligned}
$$

or

$$
\Delta \mathrm{P}_{2-G E L}=3.368\left(\Delta \mathrm{P}_{1}-2 \Delta \mathrm{P}_{\mathrm{S}}\right)
$$

and

$$
\Delta P_{2}=2 \Delta P_{S}+3.368\left(\Delta P_{I}-2 \Delta P_{S}\right)
$$

Solving for $\Delta \mathrm{P}_{S}$, we obtain

$$
\Delta P_{\mathrm{S}}=0.711 \Delta \mathrm{P}_{1}-0.211 \Delta \mathrm{P}_{2}
$$

Table 3-3 shows the pressure drop data from this test. The last colum 1nd1cates how many inches of 8-10 mesh sillca gel a single plugged screen is equivalent to in terms of pressure drop (since bed sizes are typically on the order of $1 \mathrm{lnch}$ ). Since this value is about $250 \mathrm{~Pa}$ ( $1 \mathrm{ln}$. WG) for the typical $0.33 \mathrm{~m} / \mathrm{s}$ (65 ft/min) face velocity for a $2.5-\mathrm{cm}(1-1 \mathrm{n} \cdot)-$ deep sillca gel bed, the two screens combined account for two-thirds of the total bed pressure drop. Thus, there seems to be considerable potential for reducing fan power for thin-packed beds with better screen designs.

\subsection{MBASURERRRT ACCURACT}

Accuracles of Individual measurements have been discussed; they are summarized here in Table 3-4.

The accuracy of the flow measurement actually depends on the degree of damper leakage. Although we measured the leakage rates as a function of internal duct pressure and corrected them, leakage can change with time. A more conservative estimate of flow rate measurement accuracy would be $\pm 5 \%$ of the reading. Of course, whenever different measurements are combined to obtain a calculated result, the accuracy of that result is a function of the Individual measurement accuracies. The only calculated quantity of interest in terms of 
Table 3-3. Pressure Drop v8. Flow Rate for 30-cm(12-in.)-Dianeter Test Articles and Contaiment Screens

\begin{tabular}{|c|c|c|c|c|c|c|c|c|}
\hline \multicolumn{2}{|c|}{ Flow Rate } & \multicolumn{2}{|c|}{$\Delta \mathrm{P}_{\mathrm{A}}$} & \multicolumn{2}{|c|}{$\Delta \mathrm{P}_{\mathrm{B}}$} & \multicolumn{2}{|c|}{$\Delta \mathrm{P}_{\mathrm{S}}$} & \multirow{2}{*}{$\Delta \mathrm{P}_{\mathrm{S}} / \Delta \mathrm{P}_{\mathrm{R}}$} \\
\hline $\mathrm{kg} / \mathrm{s}$ & sc fm & $\mathrm{Pa}$ & In. WG & $\mathrm{Pa}$ & in. WG & $\mathrm{Pa}$ & 1n. WG & \\
\hline 0.023 & 40 & 159 & 0.639 & 301 & 1.208 & 49.8 & 0.200 & 0.988 \\
\hline 0.034 & 60 & 297 & 1.191 & 554 & 2.224 & 94.1 & 0.378 & 1.030 \\
\hline 0.045 & 80 & 459 & 1.842 & 886 & 3.546 & 140 & 0.561 & 0.927 \\
\hline 0.057 & 100 & 647 & 2.600 & 1250 & 5.030 & 196 & 0.788 & 0.913 \\
\hline 0.068 & 120 & 865 & 3.475 & 1650 & 6.614 & 268 & 1.075 & $\frac{0.964}{0.06}$ \\
\hline
\end{tabular}

No tes :

$\Delta \mathrm{P}_{\mathrm{A}}=$ pressure drop across $3-\mathrm{cm}\left(1.2-1 \mathrm{n}_{0}\right)$ bed.

$\Delta \mathrm{P}_{B}=$ pressure drop across $10-\mathrm{cm}(4-\mathrm{ln} \cdot)$ bed.

$\Delta \mathrm{P}_{\mathrm{S}}=$ pressure drop across a single installed screen.

$\Delta \mathrm{P}_{\mathrm{R}}=$ pressure drop across $2.5 \mathrm{~cm}$ (1 ln.) of sllica gel (reference).

Table 3-4. Accuracies of Individual Measurements

\begin{tabular}{ll}
\hline \multicolumn{1}{c}{ Measurement } & \multicolumn{1}{c}{ Accuracy } \\
\hline Type-T thermocouples & $\pm 0.5^{\circ} \mathrm{C}$ \\
Pressure & $\pm 0.5 \%$ of reading \\
Dew point & $\pm 0.56^{\circ} \mathrm{C}$ \\
Flow rate & $\pm 1 \%$ of reading \\
\hline
\end{tabular}

the plotted results is the air humidity ratio $\mathrm{W}$, which is a function of dewpoint temperature and measured pressure. The root-mean-square uncertainty in W is determined as follows:

$$
\mathrm{W}=0.622 \frac{\mathrm{P}_{2}}{\mathrm{P}_{1}-\mathrm{P}_{2}},
$$

where

$$
\mathrm{P}_{2}=\exp \left[23.2-\frac{3780}{\mathrm{~T}_{\mathrm{DP}}+273}-\frac{225805}{\left(\mathrm{~T}_{\mathrm{DP}}+273\right)^{2}}\right]
$$

and

where

$$
\Delta \mathrm{W}=\left[\left(\frac{\partial \mathrm{W}}{\partial \mathrm{P}_{2}} \Delta \mathrm{P}_{2}\right)^{2}+\left(\frac{\partial \mathrm{W}}{\partial \mathrm{P}_{1}} \Delta \mathrm{P}_{1}\right)^{2}\right] 1 / 2
$$

$$
\Delta \mathrm{P}_{1}=0.005 \mathrm{P}_{1}
$$

and

$$
\Delta \mathrm{P}_{2}=\left(\frac{\partial \mathrm{P}_{2}}{\partial \mathrm{T}_{\mathrm{DP}}}\right) \Delta \mathrm{T}_{\mathrm{DP}}
$$


where

$$
\Delta T_{D P}=0.45^{\circ} \mathrm{C}
$$

Calculating the partial derivatives and solving for the uncertainty in humidity ratio $\Delta W$ yields:

$$
\begin{aligned}
\Delta W=\left(\left\{0 . 3 4 8 P _ { 2 } \left[\frac{1}{P_{1}-P_{2}}+\right.\right.\right. & \left.\left.\frac{P_{2}}{\left(P_{1}-P_{2}\right)^{2}}\right]\left[\frac{3780}{\left(T_{D P}+273\right)^{2}}+\frac{451610}{\left(T_{D P}+273\right)^{3}}\right]\right\}^{2} \\
& \left.+\left[\frac{0.00311 P_{1} P_{2}}{\left(P_{1}-P_{2}\right)^{2}}\right]^{2}\right)^{1 / 2} .
\end{aligned}
$$

For a typical experimental run, the percentage of error in the humidity ratio is

$$
\frac{\Delta \mathrm{W}}{\mathrm{W}} \times 100 \simeq 2.6 \%
$$

Thus, the plotted humidity ratios have an uncertainty of less than $3 \%$. 


\section{SEPY}




\section{SECTION 4.0 \\ CONCLUSIONS AND FROPOSED FUTURE WORR}

From these first sets of laboratory experimental runs, we can conclude the following:

- The SERI Desiccant Test Laboratory is a useful tool for determining the adsorption/desorption performance of desiccant beds in sizes up to full scale [5300 W (1-1/2 ton)] •

- The SERI desiccant computer model, DESSIM, shows very good agreement (within 5\%) with experimental results for adsorption runs. A change in the Lewis number was made to achieve agreement for desorption runs of within $20 \%$.

- The pressure drop across the screens in thin, packed desiccant beds can be significant and warrants investigating to reduce system fan power requirements. In a $2.5-\mathrm{cm}\left(1-1 \mathrm{n}_{\bullet}\right)-t h i c k$ bed, pressure drop across the screens accounted for two-thirds of the total bed pressure drop.

- Experimental data Indicate that mass transfer in a silica gel bed occurs more readily in the adsorption direction than the desorption direction. The effective Lewis number for regeneration is 9, compared to 3 in the case of adsorption. The mass transfer wave is also sharper in the desorption case than in adsorption.

Future laboratory work will concentrate on determining a more reliable means for measuring alr molst ure content and on bullding and testing a channel-flow desiccant bed. Analytical and experimental work done thus far suggests that a channel-flow desiccant bed ylelds a higher ratio of mass transfer coefficlent to friction factor. Thus it shows more promise than the packed-bed desiccant design for reducing power requirements while retalning good mass transfer capability. Therefore, further SERI work will concentrate on this concept as a means of maximizing overall system performance. 


\section{SEPI}




\section{SECTION 5.0}

\section{REPERBHCES}

$12 / 81$

Barlow, Robert S. 1981. Analysis of the Adsorption Process and of Desiccant Cooling Systems: A Pseudo-Steady-State Model for Coupled Heat and Mass Transfer. SERI/FR-631-1330, Golden, CO: Solar Energy Research Institute.

Rousseau, J. 1981(Oct.). Development of a Solar Desiccant Dehumidifier: Phase II Second Technical Progress Report. 81-18436. Torrance, CA: AiResearch Manufacturing Company.

Threlkeld, James L. 1970. Thermal Environmental Engineering. 2nd Ed. Englewood Cliffs, NJ: Prentice-Hall, Inc.

van Leersum, J. 1981(0ct.). Personal Communication. Commonwealth Scientific and Industrial Research Organization, Highett, Australia.

Wurm, J. et al. 1979. Solar-MEC Development Program: Project G1019 Semiannual Progress Report for the Period September 1, 1978, Through March 31, 1979. C00-4495-23. Chicago, IL: Institute of Gas Technology. 
$\therefore$

SFPI* 


\section{APPENDIX}

\section{DESICCANT LABORATORY EXPERTMENTAL PROCEDURE}

\section{REgENERATION PREPARATION}

1. Open D-2, D-3, D-4, and D-6. Close D-1 and D-5 (a11 butterflies open).

2. Turn on fan $F-2$.

3. Ad just $B-5$ and $B-6$ to desired flow rate.-

4. Turn on $35-\mathrm{kW}$ heater and set temperature.

5. When desired temperature is reached, readjust $B-5$ and $B-6$ if desired, and note flow rate.

6. Turn off $35-\mathrm{kW}$ heater.

7. When temperature drops within $10^{\circ} \mathrm{C}$ of ambient, turn off fan $\mathbf{F - 2}$.

\section{ADSORPTION PREPARATION}

1. Open dampers $D-1, D-3, D-4$, and $D-5$. Close $D-2$ and $D-6$.

2. Turn on boller (make sure relays engage).

3. Turn on fan $F-1$.

4. Adjust butterflies $B-1$ and $B-2$ for desired flow.

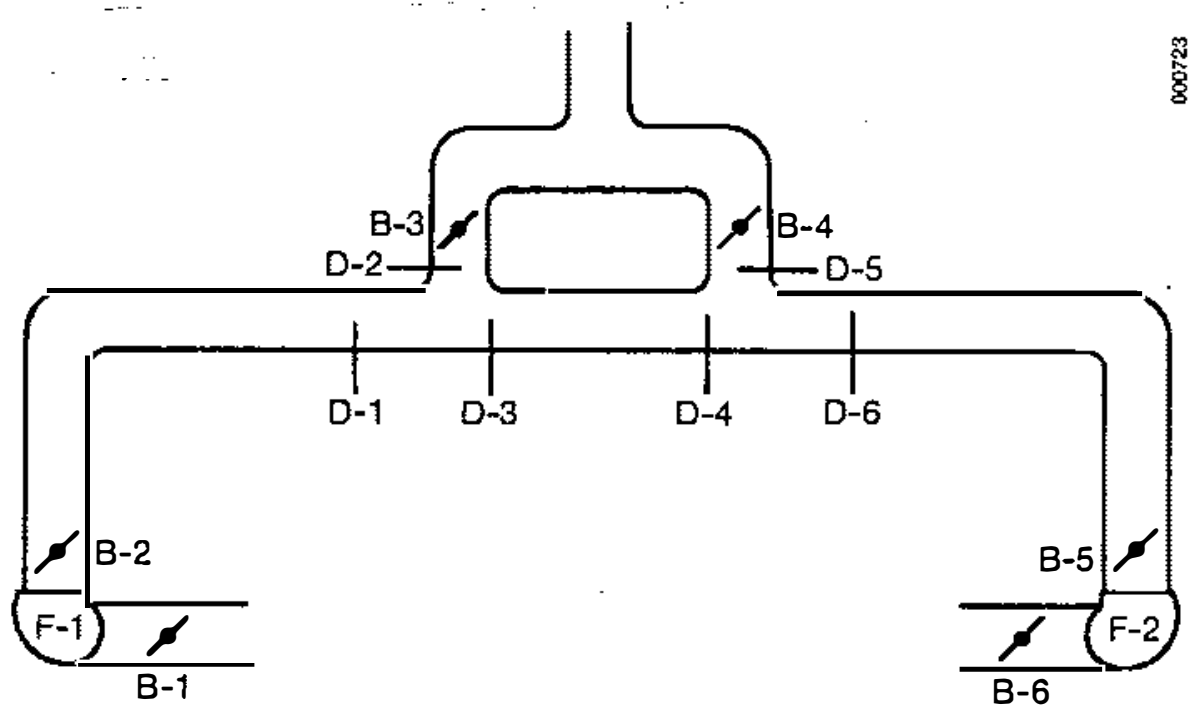

Shutoff Dampers: D-1 - D-6 (Open or Closed)

Butterfly Dampers: B-1 - B-6 (Adjustable)

Fans: $F-1, F-2$

Pigure A-1. Schematic of the SERI Desiccant Test Loop Showing Positions of Dampers and Fans 
5. Turn on 6-kW heater and set temperature.

6. When desired temperature is reached, readjust $B-1$ and $B-2$, if desired. (Optional: Run steam into loopt)

7. Turn off $6-\mathrm{kW}$ heater.

8. When temperature drops to within $5^{\circ} \mathrm{C}$ of ambient, turn off $\mathrm{F}-1$.

9. When boller has reached maximum pressure, shut it off.

\section{RBGBIERATION (MONDATA)}

1. Close dampers $\mathrm{D}-1, \mathrm{D}-2, \mathrm{D}-3$, and $\mathrm{D}-4$. Open $\mathrm{D}-5$ and $\mathrm{D}-6$.

2. Turn on fan F-2.

3. Turn on 35-kW heater and set temperature.

4. When desired temperature is reached, adjust B-4 to get desired flow rate.

5. Open D-2, D-3, and D-4. Close D-5.

6. When bed outlet temperature is within $0.2^{\circ} \mathrm{C}$ of bed inlet temperature, run is over. Open D-5. Close $D-3$ and $D-4$.

7. Turn off $35-\mathrm{kW}$ heater.

8. When temperature drops to within $10^{\circ} \mathrm{C}$ of ambient, turn off fan $\mathrm{F}-2$.

\section{ADSORPTION (DATA RUR)}

1. Turn on boller and set power level.

2. Open D-1 and B-4. Close D-6.

3. Turn on fan $F-1$.

4. Turn on 6-kW heater and set temperature.

5. When desired temperature is reached, adjust B-3 to get flow (from adsorption preparation).

6. Input desired dew point to computer and open steam supply valves.

7. Open D-4 and D-3. Close D-2.

8. When outlet conditions are sufficlently close to inlet conditions, adsorption run is over. Open D-2. Close $D-3$ and $D-4$.

9. Close steam supply valves and shut off boller.

10. Shut off 6-kW heater.

11. When temperature has dropped to within $5^{\circ} \mathrm{C}$ of ambient, turn off fan F-1.

\section{REGENERATION (DATA)}

1. Close $D-1$. Open $D-6$ and $B-3$.

2. Repeat steps 2 through 8 of III, "Regeneration (Nondata)." 


\section{NEH ADSORPTION RDN (DATA)}

1. Turn on boiler.

2. Open $D-1, D-2$, and $B-4$. Close $D-6$.

3. Turn on fan $F-1$.

4. Turn on $6-\mathrm{kW}$ heater.

5. When desired temperature is reached, adjust B-3 to get previous adsorption run flow.

6. Adjust $B-1$ and $B-2$ to get new desired flow rate.

7. Input desired dew point to computer and open steam supply valves.

8. Open $D-4$ and $D-3$. Close D-2.

9. When outlet conditions are sufficiently close to inlet conditions, the adsorption run is over. Open $\mathrm{D}-2$. Close $\mathrm{D}-3$ and $\mathrm{D}-4$.

10. Close steam supply valves and shut off boiler.

11. Shut off $6-\mathrm{kW}$ heater.

12. When temperature has dropped to within $5^{\circ} \mathrm{C}$ of ambient, turn off fan F-1.

\section{NET REGENERATION RON (DATA)}

1. Open $D-6$ and $B-3$. Close $D-1$.

2. Turn on fan F-2.

3. Turn on $35-\mathrm{kW}$ heater.

4. When desired temperature is reached, adjust B-4 to get previous regeneration flow rate.

5. Ad just $B-5$ and $B-6$ to get new desired flow rate.

6. Open D-2, D-3, and D-4. Close D-5.

7. When bed outlet temperature is within $0.2^{\circ} \mathrm{C}$ of inlet, the run is over. Open D-5. Close $\mathrm{D}-3$ and $\mathrm{D}-4$.

8. Turn off $35-\mathrm{kW}$ heater.

9. When temperature drops to within $10^{\circ} \mathrm{C}$ of ambient, turn off fan $\mathrm{F}-2$.

Procedures VI and VII can be alternately repeated as desired.

Note: Section I (1 through 5) can be done at the beginning of Section III but should not be repeated in Section $V$. 


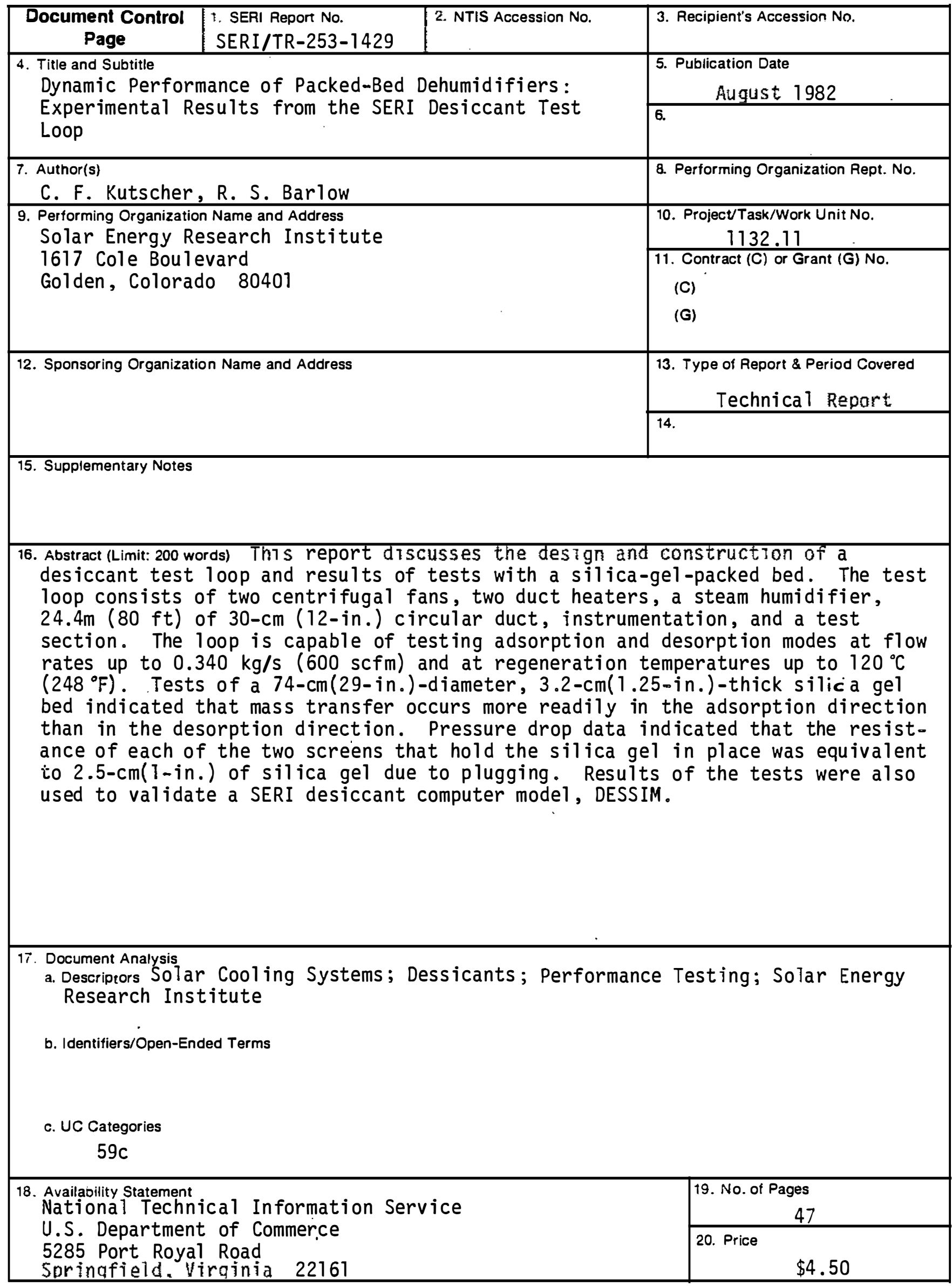

